\title{
Geochemical and fractal analysis of enclaves in the Dehe-Bala intrusion, (Northwestern Iran): a new concept in the interpretation of the crust-mantle interaction process
}

\author{
Zeynab GHARAMOHAMMADI ${ }^{1}$, Ali KANANIAN ${ }^{1, *}$ and Mohsen ELIASSI ${ }^{1}$ \\ 1 School of Geology, College of Science, University of Tehran, Tehran, Iran
}

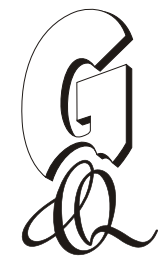

Gharamohammadi, Z., Kananian, A., Eliassi, M., 2019. Geochemical and fractal analysis of enclaves in the Dehe-Bala intrusion, (Northwestern Iran): a new concept in the interpretation of the crust-mantle interaction process. Geological Quarterly, 63 (3): 505-521, doi: 10.7306/gq.1481

Associate editor: Wojciech Granoszewski

The Dehe-Bala intrusion is one of the remarkable intrusions of granodiorite rocks with I-type affinity and abundant mafic microgranular enclaves (MMEs) in the Buin Zahra area, Qazvin, Iran. The MMEs, composed of diorite and quartz-monzodiorites, are haphazardly widespread in the granodiorites. The Dehe-Bala Granodiorites (DBG) usually are characterized by high contents of $\mathrm{SiO}_{2}$ (64.2-66.9), $\mathrm{Na}_{2} \mathrm{O}$ (3-3.23), $\mathrm{K}_{2} \mathrm{O}$ (3.49-4), Mg\# 4.84 and Th/Ta ratio ( $\left.\approx 7.9\right)$. In comparison to the DBG, the MMEs can be distinguished by their lower value of $\mathrm{SiO}_{2}(52.8-58.2), \mathrm{K}_{2} \mathrm{O}(1.4-3.8)$ and higher Mg\# (0.4-0.46). All these characteristics show a different composition of the DBG and MMEs, more importantly, can argue in favor of a magma mixing/mingling origin in the DBG. The enrichment in total REEs and HFSEs in the MMEs clearly reflects a marked diffusional process from the felsic to mafic magma that could have been achieved by chemical exchange during the magma mixing/mingling process. The fractal dimensions $\left(D_{\text {box }}\right)$ of MMEs differ from 1.14 to 1.29 with the highest frequency at 1.29. The textural heterogeneity and geochemical features combined with high $D_{b o x}$ values in the MMEs compared with the DBG show lower degrees of mixing/mingling between mantle-derived mafic and lower crust-derived felsic magmas.

Key words: Dehe-Bala Granodiorites (DBG), mafic microgranular enclaves (MMEs), magma mixing, fractal dimension of enclaves.

\section{INTRODUCTION}

I- and S-type granites have been widely recognized all over the world (Chappell and White, 1974). S-type granitic melts, which form under fluid-present conditions, are rheologically different from l-type granites (Castro, 2013). It is crucial to know the sources of I-type granites, due to the significant role of continental crust in magma generation. Furthermore, these melts are generally formed because of partial melting under fluid-absent conditions; however, more mafic granites (calc-alkaline granodiorites) cannot consist of pure partial melt of crustal rocks (Clemens and Stevens, 2012).

From another point of view, the presence of disequilibrium textures and mafic microgranular enclaves (MMEs) in calc-alkaline plutons is strong evidence of small-scale diffusion. MMEs seems to control compositional heterogeneity in igneous systems following magma mixing (Perugini et al., 2003). There are various models and hypotheses addressing the geochemi-

* Corresponding author, e-mail: kananian@ut.ac.ir

Received: August 7, 2018; accepted: May 28, 2019; first published online: August 8, 2019 cal diversity of I-type granites. Experimental melts, geochemical and isotopic data and the presence of mafic and felsic microgranular enclaves in I-type plutons indicate that calc-alkaline I-type granitic magmas resulted from mixing/mingling of mafic and felsic magmas (Collins, 1996; Kemp et al., 2007). The high Fe and $\mathrm{Mg}$ content in the majority of granodioritic and tonalitic magmas arises due to the entrance of peritectic minerals from the protolith. This indicates that the nature of the magma generated was also significantly influenced by the type and frequency of these minerals (Clemens and Stevens, 2012). The study of MMEs is a unique opportunity in the recognition of petrogenesis and the source of granitoid magmas (Perugini et al., 2003; Barbarin, 2005). MMEs provide evidence for mantle-crust interaction during the mixing/mingling process (Zhao et al., 2012). Recently, magma mixing has been regarded as a chaotic process in magma chambers which results in the formation of fractal structures (Perugini and Poli, 2012). The focus of this study is on magma mixing/mingling evidence in the DBG. This study presents details of the mineralogy, petrology and geochemical features of granodiorites and their MMEs from the Dehe-Bala suite. Furthermore, this study provides a distinct approach to discussion of the magma mixing/mingling process. We estimate the fractal dimension of MMEs $\left(D_{b o x}\right)$ by using the complexity of the MMEs' morphology. The main goal of this work is to clarify the degrees of mixing/mingling between crust 

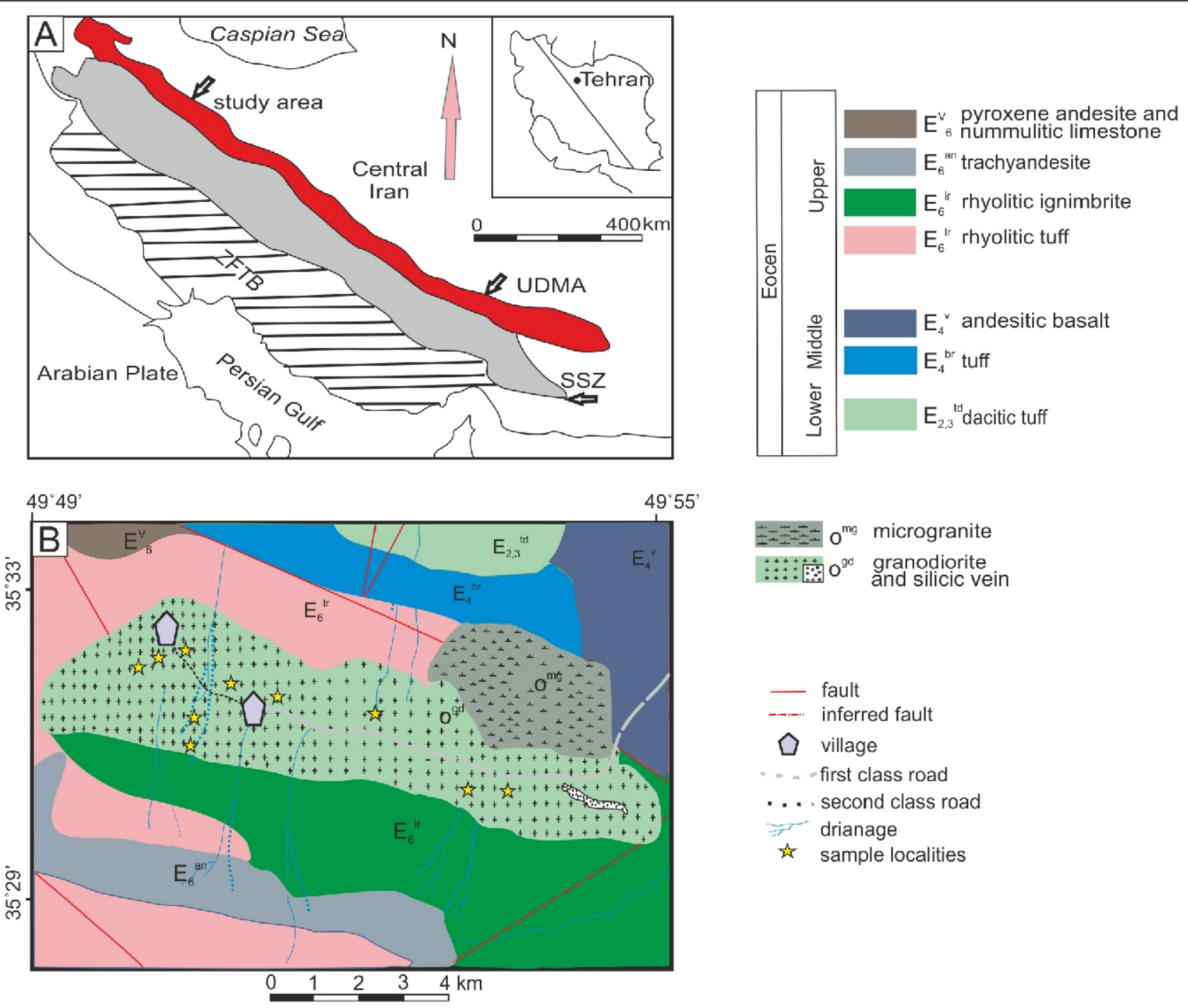

Fig. 1A - simplified map of tectonic zones of the Zagros Orogenic Belt, Urumieh-Dokhtar Magmatic Assemblage (UDMA), Sanandaj-Sirjan Zone (SSZ), Zagros Fault Thrust Belt (ZFTB); B - simplified geological map of the DBG in south-west Buin Zahra (after Eghlimi, 2000)

and mantle components involved in the genesis of the granodiorites and their MMEs. Finally, the fractal dimensions of the MMEs and the geochemical data provide direct assessment of the viscosity of the felsic and mafic end-members.

\section{GEOLOGICAL SETTING}

According to field and petrographic observations, the Paleogene intrusive rocks within the Buin Zahra area mainly consist of gabbro, diorite, quartz diorite, quartz monzonite and granite (Tabakhe Shabani, 1990). Some of these granitoids notably include abundant MMEs, and their shapes, colours and textures reflect the magma mixing/mingling process as well as the geochemical reactions between mantle- and crust-derived magmas (Safarzadeh, 2007).

The DBG is part of the Urumieh-Dokhtar Magmatic Assemblage (UDMA), which is located about $45 \mathrm{~km}$ south-west of Buin Zahra, Qazvin Province, Northwestern Iran. Formation of the UDMA resulted from subduction of the Neotethyan oceanic lithosphere beneath the southwestern margin of the Central
Iran microcontinent. The UDMA is characterized by volcanic successions and intrusive complexes (Berberian and King, 1981; Agard et al., 2011). Rocks older than Eocene are missing in the Dehe-Bala-Agh-Ghoyu region. The Eocene and Oligocene rocks of the UDMA normally classify as of calc-alkaline (Berberian and King, 1981) and, in some cases, alkaline affinity (Moradian, 1997). As a result of compressive events in the Late Eocene-Oligocene, the DBG has intruded into Eocene volcanic and sedimentary rocks and a narrow thermal metamorphic contact aureole has been formed in the host rocks (Tabakhe Shabani, 1990).

Field observations show that the Dehe-Bala intrusion mainly consists of light and dark grey granodiorites. All rock units of the DBG have a soft morphology with weathered and altered surfaces. The MMEs are randomly scattered, $2-30 \mathrm{~cm}$ in size in the DBG, and typically possess ellipsoidal and rounded shapes, so that various other shapes such as crusty, angular, schlieren and extremely elongated enclaves are very rare in the DBG. The MMEs also display sharp and irregular contacts with their host rocks. In comparison with the host rocks, MMEs are identified by a fine-grained texture and dark colour (Figs. 1 and 2). 

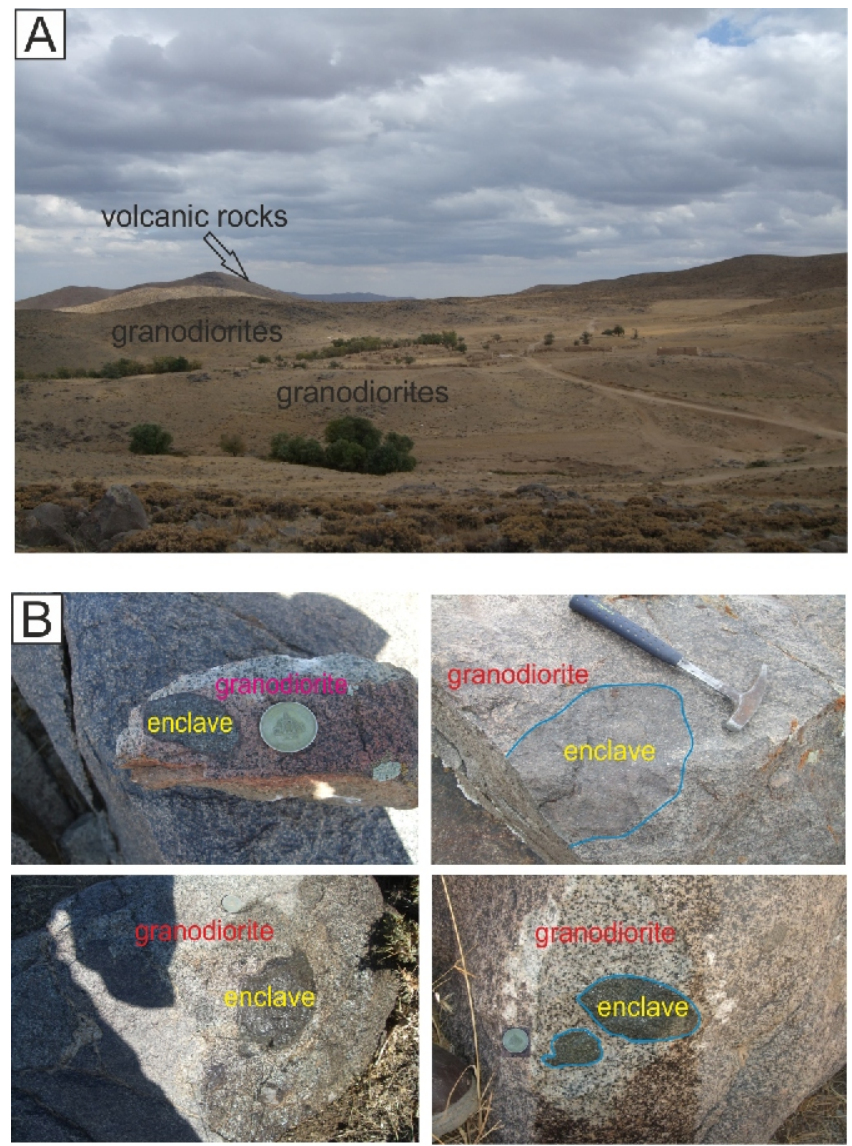

Fig. 2. The pictures of granodiorites $(A)$ and mafic microgranular enclaves (B) in Dehe-Bala area

\section{ANALYTICAL METHODS}

After petrological and field observations, 60 samples of felsic rocks and MMEs were collected from the DBG. Detailed petrographic surveys were performed on 50 thin sections. 16 fresh samples (10 host rocks and 6 enclaves) were selected based on their various mineralogy and texture. Each sample was crushed into 200 mesh for whole-rock major and trace element analysis.

The major and trace elements of samples were measured by ICP-AES ICP-MS method in ALS Chemex Lab, Loughrea, Ireland (code, ME-MS81). The above-mentioned methods were selected due to lower detection limits and good accuracy in geochemical analysis. The detection limit for major elements, trace elements and rare earth elements was 0.01 wt. \%, 0.10-1 ppm, 0.01-0.5 ppm, respectively. A lithium borate fusion of the sample prior to acid dissolution and ICP-MS analysis provides the most quantitative approach for a broad suite of trace elements. This technique solubilizes most mineral species, including those that are highly refractory. Options for adding the whole rock elements from an ICP-AES analysis from the same fusion, or base metals from a separate four-acid digestion, are available.

\section{RESULTS}

\section{PETROGRAPHY}

The Dehe-Bala intrusion is mainly composed of granodiorites that in some places gradually grade into quartz monzodiorite; however, there is no clear distinction between them. All samples consist of quartz (6-20 wt.\%), plagioclase (40-48 wt.\%), K-feldspar (20-30 wt.\%), biotite (5-18 wt.\%), amphibole (3-12 wt.\%) and clinopyroxene (1-2 wt.\%). Accessory phases mainly include apatite, zircon, titanite and opaques (1-2 wt.\%).

Quartz occurs as irregular interstitial phases with undulatory extinction between plagioclase, K-feldspar and mafic minerals Plagioclase crystals generally are euhedral and subhedral and display zoning and polysynthetic twins. Individual phenocrysts show resorption surfaces, and sieve and poikilitic textures. Plagioclases have been partially altered to sericite, epidote and calcite. K-feldspar is present as small to large crystals; some poikiolitic grains often enclose plagioclase, biotite, quartz, hornblende and apatite. Locally, K-feldspar grains ae replaced by clay minerals. Biotite, amphibole and pyroxene are generally observed as euhedral and anhedral crystals of different sizes. Brown biotite is the dominant phase in the granodiorites with obvious corrosion of some crystals. Certain biotites and pyroxenes are altered to chlorite and actinolite, respectively.

Most MME samples are quartz diorite and quartz monzodiorite in composition. The MMEs have similar mineral assemblages to the host granitoids except for the greater abundance of plagioclase and mafic minerals, such as hornblende. Granular to microgranular, poikilitic and sieve textures are observed in the MMEs. The MMEs are characterized by smaller grain size and are darker than the host granodiorites. Chilled margins are observed along some boundaries of the enclaves. There are two types of quartz in the MMEs: the first type is observed as anhedral and small interstitial phases; the second type comprises quartz xenocrysts often surrounded by fine-grained biotite (quartz ocelli). Plagioclases are observed as euhedral to subhedral grains and display polysynthetic twining and repeated resorption surfaces (Fig. 3). Plagioclase crystals usually exist along the boundaries of MMEs and the host rock, on both sides (Fig. 3). K-feldspar crystals are irregular and sometimes in the form of large xenocrysts containing fine-grained plagioclase, biotite, quartz, hornblende, and apatite (poikilitic texture). Mafic minerals (hornblende, biotite, amphibole and pyroxene) appeared in different sizes and of euhedral to anhedral form. Some fine-grained mafic clots composed of mafic minerals such as biotite, amphibole and titanite are observed in both MMEs and the host rock. Apatite is the most common accessory mineral in most MMEs. Acicular apatite is observed in MMEs but apatite occurs as thick and prismatic crystals in the host rocks (Fig. 3).

\section{GEOCHEMISTRY}

Geochemical analyses of the host granodiorites and MMEs are shown in Tables 1 and 2. Samples of the Dehe-Bala intrusion are located in the granodiorite field on a total alkali against $\mathrm{SiO}_{2}$ (TAS) classification diagram (Fig. 4A). Based on the aluminum saturation index, all granodiorite samples are metalu- 

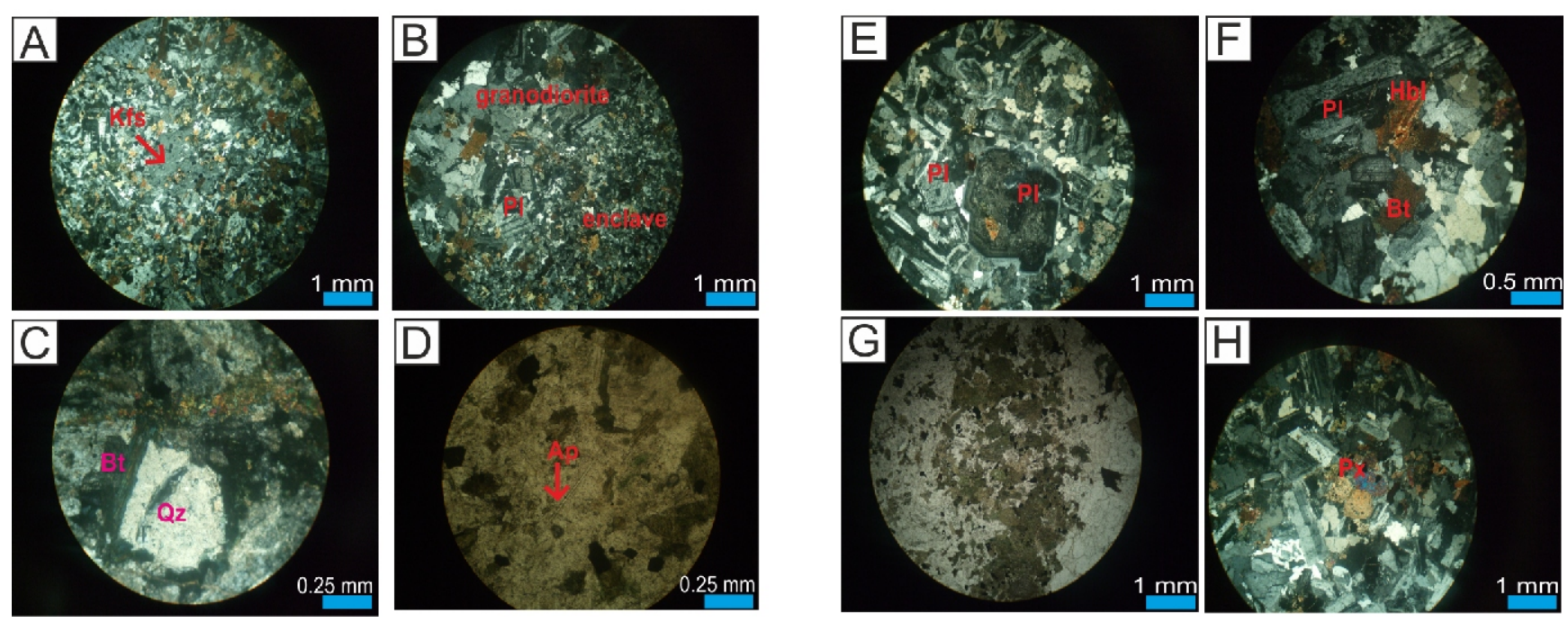

Fig. 3. Photomicrographs of granodiorite host (right) and mafic enclave (left)

A - poiklitic K-feldspar (Kfs) (xpl); B - the presence of plagioclase $(\mathrm{PI})$ in the boundary between the enclave and granodiorite (xpl); $\mathbf{C}-$ ocelli quartz (Qz) and biotite (Bt) (xpl); D - apatite (Ap) acicular apatite in MMEs (xpl); E - large plagioclase (PI) with resorption surface (xpl); $\mathbf{F}$ plagioclase, hornblende $(\mathrm{Hbl})$ and biotite $(\mathrm{Bt})(\mathrm{xpl}) ; \mathbf{G}$ - the mafic clots in granodiorite matrix (ppl); $\mathbf{H}$ - pyroxene (Px), (xpl); mineral abbreviations from Kretz (1983)
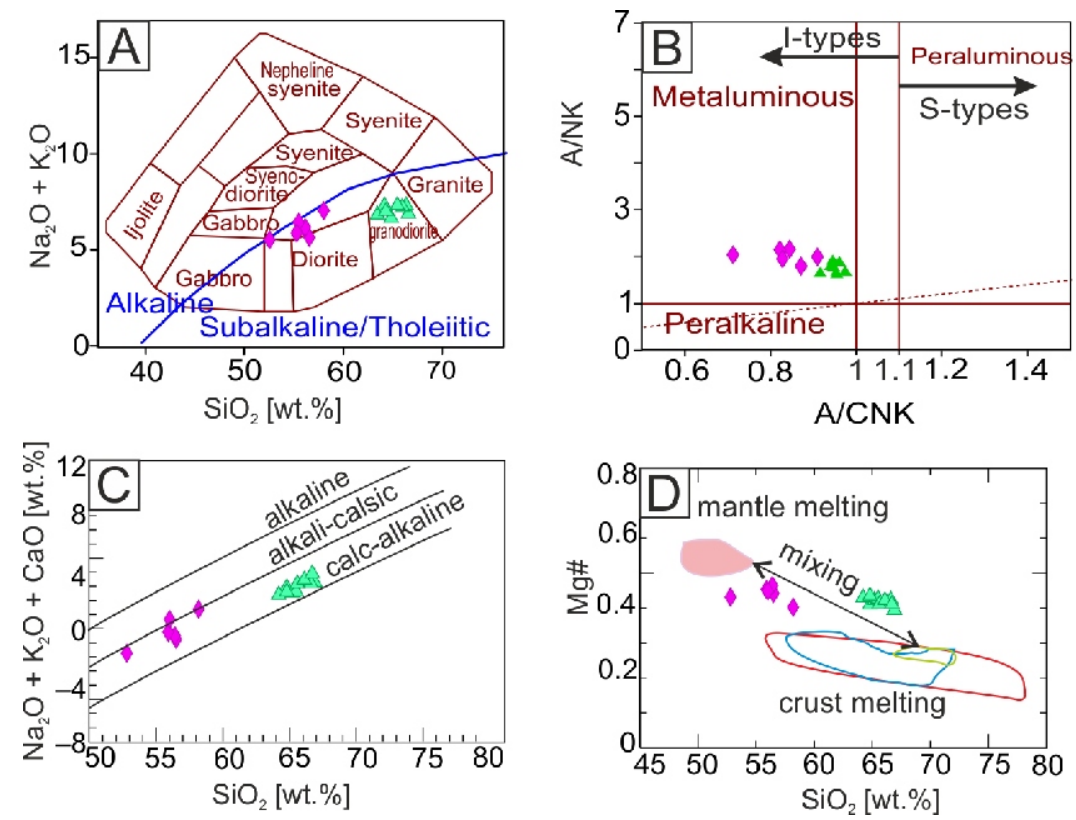

Pure crustal partial melt at $7 \mathrm{kbar}$ and $825-950^{\circ} \mathrm{C}$

$$
\overbrace{}^{2}
$$

Pure crustal partial melt at $7-13 \mathrm{kbar}$ and $825-950^{\circ} \mathrm{C}$

Pure crustal partial melt at $8-16 \mathrm{kbar}$ and $1000-1050^{\circ} \mathrm{C}$

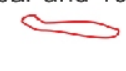

Fig. 4A - plot of total alkalis against silica (modified from Wilson, 2007); B - plot of A/NK vs. A/CNK (Maniar and Piccoli, 1989); $\mathrm{C}$ - calc-alkaline rocks and rich in potassium as evidences by $\mathrm{K}_{2} \mathrm{O}+\mathrm{Na}_{2} \mathrm{O}+\mathrm{CaO}$ against $\mathrm{SiO}_{2}$ diagram (Frost et al., 2001); $\mathrm{D}-\mathrm{Mg} \#$ versus $\mathrm{SiO}_{2}$ diagram, the shaded fields represent experimental studies of pure crustal partial melts (see Patiño Douce and Johnston, 1991; Rapp and Watson, 1995; Sisson et al., 2005 for detailed) 
Ta ble 1

Major oxide and trace element contents in the Dehe-Bala MMEs

\begin{tabular}{|c|c|c|c|c|c|c|}
\hline SAMPLE & DA40 & DA41 & DA42 & DA43 & DA1 & DA5 \\
\hline \multicolumn{7}{|c|}{ [wt.\%] } \\
\hline $\mathrm{SiO}_{2}$ & 56.5 & 56.4 & 58.2 & 55.9 & 56 & 52.8 \\
\hline $\mathrm{Al}_{2} \mathrm{O}_{3}$ & 17 & 16.8 & 17.05 & 16.8 & 17 & 16.3 \\
\hline $\mathrm{Fe}_{2} \mathrm{O}_{3}{ }^{(\mathrm{t})}$ & 8.78 & 8.1 & 8.57 & 7.9 & 8.59 & 9.99 \\
\hline $\mathrm{CaO}$ & 6.46 & 6.39 & 5.23 & 6.27 & 5.31 & 7.08 \\
\hline $\mathrm{MgO}$ & 3.5 & 3.53 & 2.9 & 3.29 & 3.52 & 3.81 \\
\hline $\mathrm{Na}_{2} \mathrm{O}$ & 3.57 & 3.47 & 4.36 & 3.5 & 3.96 & 4.17 \\
\hline $\mathrm{K}_{2} \mathrm{O}$ & 2.14 & 2.42 & 2.25 & 2.52 & 2 & 1.17 \\
\hline $\mathrm{TiO}_{2}$ & 0.94 & 0.91 & 0.91 & 1.05 & 0.99 & 1.12 \\
\hline $\mathrm{MnO}$ & 0.23 & 0.23 & 0.16 & 0.19 & 0.21 & 0.26 \\
\hline $\mathrm{P}_{2} \mathrm{O}_{5}$ & 0.2 & 0.26 & 0.23 & 0.18 & 0.21 & 0.17 \\
\hline $\mathrm{Cr}_{2} \mathrm{O}_{3}$ & $<0.01$ & 0.01 & $<0.01$ & $<0.01$ & $<0.01$ & 0.01 \\
\hline $\mathrm{SrO}$ & 0.03 & 0.03 & 0.02 & 0.03 & 0.03 & 0.03 \\
\hline $\mathrm{BaO}$ & 0.05 & 0.06 & 0.05 & 0.05 & 0.06 & 0.04 \\
\hline LOI & 1.03 & 1.15 & 1.45 & 0.89 & 1.78 & 1.57 \\
\hline Total & 100 & 99.76 & 101.4 & 98.57 & 99.6 & 98.5 \\
\hline \multicolumn{7}{|c|}{ [ppm] } \\
\hline $\mathrm{Ba}$ & 384 & 489 & 441 & 468 & 525 & 424 \\
\hline $\mathrm{Ce}$ & 61.6 & 82.1 & 46.4 & 53.8 & 47 & 67.5 \\
\hline $\mathrm{Cr}$ & 10 & 20 & $<10$ & $<10$ & $<10$ & 20 \\
\hline Cs & 4.76 & 3.03 & 6.91 & 4.22 & 2.48 & 2.56 \\
\hline Dy & 7.54 & 7.22 & 5.53 & 4.8 & 5.26 & 6.13 \\
\hline $\mathrm{Er}$ & 4.53 & 4.41 & 3.18 & 3.03 & 3.23 & 3.5 \\
\hline $\mathrm{Eu}$ & 1.13 & 1.05 & 0.92 & 1.12 & 0.95 & 1.24 \\
\hline $\mathrm{Ga}$ & 20.2 & 20.2 & 19.9 & 19.3 & 20.8 & 22.6 \\
\hline $\mathrm{Gd}$ & 7.49 & 7.22 & 5.62 & 4.99 & 5.44 & 6.2 \\
\hline $\mathrm{Hf}$ & 3 & 3.7 & 3.1 & 3.4 & 3.6 & 2.4 \\
\hline Ho & 1.49 & 1.48 & 1.09 & 0.99 & 1.05 & 1.22 \\
\hline La & 29.1 & 44.6 & 23.2 & 28.3 & 22.5 & 31.7 \\
\hline Lu & 0.69 & 0.65 & 0.48 & 0.46 & 0.5 & 0.53 \\
\hline $\mathrm{Nb}$ & 28.3 & 30 & 23.1 & 27.8 & 29.7 & 35.2 \\
\hline $\mathrm{Nd}$ & 30.7 & 35 & 23.6 & 23.4 & 22.7 & 30.1 \\
\hline $\mathrm{Pr}$ & 7.68 & 9.39 & 5.91 & 6.24 & 5.81 & 7.77 \\
\hline $\mathrm{Rb}$ & 97.3 & 95.6 & 137 & 110 & 107 & 61.5 \\
\hline Sm & 7.26 & 7.21 & 5.31 & 4.76 & 4.91 & 6.29 \\
\hline Sn & 4 & 4 & 4 & 3 & 3 & 5 \\
\hline $\mathrm{Sr}$ & 305 & 318 & 241 & 312 & 303 & 332 \\
\hline $\mathrm{Ta}$ & 1.9 & 1.8 & 1.5 & 2 & 1.8 & 2.3 \\
\hline $\mathrm{Tb}$ & 1.23 & 1.16 & 0.9 & 0.77 & 0.88 & 0.97 \\
\hline Th & 12.5 & 10.95 & 11.05 & 11.25 & 9.18 & 9.63 \\
\hline $\mathrm{Tm}$ & 0.65 & 0.62 & 0.45 & 0.43 & 0.44 & 0.57 \\
\hline$U$ & 3.65 & 2.91 & 2.68 & 2.3 & 2.36 & 2.17 \\
\hline $\mathrm{V}$ & 183 & 162 & 152 & 189 & 170 & 246 \\
\hline W & 264 & 184 & 281 & 409 & 382 & 261 \\
\hline$Y$ & 42.2 & 42.7 & 33.4 & 29.1 & 30.9 & 35.8 \\
\hline $\mathrm{Yb}$ & 4 & 4.27 & 3.25 & 2.89 & 3.15 & 3.64 \\
\hline $\mathrm{Zr}$ & 86 & 120 & 116 & 123 & 130 & 86 \\
\hline $\operatorname{REE}_{(\mathrm{t})}$ & 176 & 216.2 & 136 & 146.5 & 132 & 176 \\
\hline $\mathrm{Eu} / \mathrm{Eu}^{*}$ & 0.47 & 0.44 & 0.51 & 0.7 & 0.56 & 0.61 \\
\hline $\mathrm{Nb} / \mathrm{Ta}$ & 14.9 & 16.66 & 15.4 & 13.9 & 16.5 & 15.3 \\
\hline $\mathrm{K}_{2} \mathrm{O} / \mathrm{Na}_{2} \mathrm{O}$ & 0.59 & 0.69 & 0.51 & 0.72 & 0.5 & 0.28 \\
\hline Mg\# & 0.44 & 0.46 & 0.4 & 0.45 & 0.44 & 0.43 \\
\hline
\end{tabular}


Major oxide and trace element concentrations in the DBG

\begin{tabular}{|c|c|c|c|c|c|c|c|c|c|c|}
\hline SAMPLE & DG2 & DG3 & DG8 & DG9 & DG10 & DG11 & DG12 & DG13 & DG16 & DG18 \\
\hline \multicolumn{11}{|c|}{ [wt.\%] } \\
\hline $\mathrm{SiO}_{2}$ & 67 & 65 & 65 & 64 & 65.5 & 64.8 & 65.6 & 66.6 & 66.1 & 66.7 \\
\hline $\mathrm{Al}_{2} \mathrm{O}_{3}$ & 15 & 16 & 16 & 16 & 15.95 & 16 & 15.7 & 15.9 & 15.6 & 15.5 \\
\hline $\mathrm{Fe}_{2} \mathrm{O}_{3}{ }^{(\mathrm{t})}$ & 4.5 & 4.9 & 5.1 & 5.3 & 4.68 & 4.89 & 4.43 & 4.66 & 4.28 & 4.02 \\
\hline $\mathrm{CaO}$ & 3.7 & 4.1 & 4.1 & 4.2 & 3.83 & 4.15 & 3.88 & 3.84 & 3.55 & 3.44 \\
\hline $\mathrm{MgO}$ & 1.5 & 1.7 & 1.9 & 2 & 1.75 & 1.89 & 1.55 & 1.72 & 1.57 & 1.41 \\
\hline $\mathrm{Na}_{2} \mathrm{O}$ & 3.2 & 3.2 & 3.2 & 3.2 & 3.32 & 3.22 & 3.06 & 3.31 & 3.14 & 3.33 \\
\hline $\mathrm{K}_{2} \mathrm{O}$ & 3.8 & 3.8 & 3.5 & 3.4 & 3.75 & 3.54 & 4 & 3.72 & 3.86 & 4.01 \\
\hline $\mathrm{TiO}_{2}$ & 0.5 & 0.6 & 0.6 & 0.6 & 0.6 & 0.61 & 0.54 & 0.58 & 0.53 & 0.51 \\
\hline $\mathrm{MnO}$ & 0.1 & 0.1 & 0.1 & 0.1 & 0.11 & 0.12 & 0.12 & 0.1 & 0.09 & 0.09 \\
\hline $\mathrm{P}_{2} \mathrm{O}_{5}$ & 0.1 & 0.1 & 0.2 & 0.2 & 0.13 & 0.16 & 0.12 & 0.15 & 0.13 & 0.12 \\
\hline $\mathrm{Cr}_{2} \mathrm{O}_{3}$ & $<0.01$ & $<0.01$ & $<0.01$ & $<0.01$ & $<0.01$ & $<0.01$ & $<0.01$ & $<0.01$ & $<0.01$ & $<0.01$ \\
\hline $\mathrm{SrO}$ & 0 & 0 & 0 & 0 & 0.02 & 0.03 & 0.03 & 0.03 & 0.03 & 0.02 \\
\hline $\mathrm{BaO}$ & 0.1 & 0.1 & 0.1 & 0.1 & 0.08 & 0.08 & 0.08 & 0.08 & 0.08 & 0.07 \\
\hline LOI & 0.7 & 0.9 & 1.3 & 1.2 & 1.02 & 1.03 & 1.8 & 0.87 & 1.03 & 1.13 \\
\hline Total & 100 & 100 & 101 & 100 & 100.7 & 101 & 101 & 102 & 99.9 & 100 \\
\hline \multicolumn{11}{|c|}{ [ppm] } \\
\hline $\mathrm{Ba}$ & 595 & 681 & 690 & 622 & 695 & 625 & 695 & 684 & 686 & 591 \\
\hline $\mathrm{Ce}$ & 52 & 58 & 52 & 52 & 49.7 & 50.5 & 56.9 & 56.8 & 52.7 & 68.7 \\
\hline $\mathrm{Cr}$ & $<10$ & $<10$ & 10 & $<10$ & $<10$ & $<10$ & $<10$ & $<10$ & $<10$ & $<10$ \\
\hline Cs & 4 & 3.5 & 2.7 & 2.7 & 4.48 & 3.37 & 4.67 & 4.39 & 3.02 & 2.61 \\
\hline Dy & 3.9 & 4.2 & 3.8 & 3.6 & 3.95 & 3.69 & 3.86 & 4.19 & 3.92 & 3.36 \\
\hline $\mathrm{Er}$ & 2.5 & 2.9 & 2.6 & 2.3 & 2.38 & 2.19 & 2.55 & 2.58 & 2.38 & 2.1 \\
\hline $\mathrm{Eu}$ & 0.9 & 0.9 & 1 & 1 & 0.92 & 1 & 0.94 & 0.91 & 0.87 & 0.83 \\
\hline $\mathrm{Ga}$ & 16 & 17 & 17 & 17 & 16.1 & 15.4 & 16.2 & 16.6 & 15.5 & 15.6 \\
\hline $\mathrm{Gd}$ & 4 & 4.6 & 4.1 & 3.9 & 3.7 & 3.99 & 3.89 & 4.2 & 3.93 & 3.61 \\
\hline $\mathrm{Hf}$ & 5.2 & 5.3 & 4.8 & 5.1 & 4.9 & 5.5 & 4.8 & 5.5 & 4.9 & 4.1 \\
\hline $\mathrm{Ho}$ & 0.8 & 0.9 & 0.9 & 0.7 & 0.77 & 0.76 & 0.79 & 0.88 & 0.81 & 0.72 \\
\hline $\mathrm{La}$ & 29 & 32 & 28 & 29 & 27.1 & 27.9 & 31.7 & 32.4 & 28.8 & 38.1 \\
\hline $\mathrm{Lu}$ & 0.4 & 0.5 & 0.4 & 0.4 & 0.4 & 0.39 & 0.4 & 0.44 & 0.4 & 0.39 \\
\hline $\mathrm{Nb}$ & 19 & 21 & 20 & 21 & 22.1 & 19.4 & 18.1 & 20.3 & 18.5 & 23.6 \\
\hline $\mathrm{Nd}$ & 22 & 23 & 21 & 21 & 20.7 & 20.9 & 22.2 & 22.7 & 20.9 & 23.8 \\
\hline $\mathrm{Pr}$ & 5.9 & 6.4 & 5.8 & 5.8 & 5.54 & 5.53 & 6.08 & 6.25 & 5.85 & 6.81 \\
\hline $\mathrm{Rb}$ & 130 & 134 & 118 & 114 & 134.5 & 121 & 138 & 133 & 137 & 155 \\
\hline $\mathrm{Sm}$ & 4.3 & 4.7 & 4.3 & 4.1 & 4.09 & 3.8 & 4.05 & 4.27 & 4.06 & 3.98 \\
\hline$S n$ & 2 & 2 & 12 & 2 & 2 & 2 & 3 & 2 & 2 & 19 \\
\hline $\mathrm{Sr}$ & 251 & 276 & 295 & 284 & 267 & 275 & 282 & 277 & 266 & 236 \\
\hline $\mathrm{Ta}$ & 1.7 & 1.8 & 2 & 1.7 & 1.6 & 1.6 & 1.5 & 1.7 & 1.7 & 2.3 \\
\hline $\mathrm{Tb}$ & 0.7 & 0.7 & 0.6 & 0.6 & 0.61 & 0.62 & 0.66 & 0.68 & 0.62 & 0.57 \\
\hline Th & 16 & 17 & 12 & 13 & 12.65 & 11.1 & 12.8 & 14.7 & 15.6 & 15.5 \\
\hline $\mathrm{Tm}$ & 0.3 & 0.4 & 0.4 & 0.3 & 0.34 & 0.32 & 0.35 & 0.36 & 0.37 & 0.33 \\
\hline$U$ & 3.3 & 3.8 & 2.6 & 2.6 & 3.02 & 2.69 & 2.52 & 3.57 & 3.06 & 2.74 \\
\hline V & 75 & 91 & 97 & 102 & 87 & 86 & 81 & 84 & 80 & 74 \\
\hline W & 495 & 433 & 734 & 415 & 363 & 445 & 628 & 424 & 639 & 891 \\
\hline $\mathrm{Y}$ & 24 & 27 & 23 & 23 & 23.4 & 22.3 & 23.5 & 24.9 & 24.7 & 21.1 \\
\hline $\mathrm{Yb}$ & 2.3 & 2.7 & 2.6 & 2.4 & 2.4 & 2.39 & 2.39 & 2.69 & 2.65 & 2.4 \\
\hline $\mathrm{Zr}$ & 187 & 191 & 178 & 191 & 194 & 197 & 177 & 203 & 180 & 166 \\
\hline $\operatorname{REE}_{(\mathrm{t})}$ & 129 & 142 & 127 & 127 & 122.6 & 124 & 137 & 139 & 128 & 156 \\
\hline $\begin{array}{l}\mathrm{Eu} / \mathrm{Eu}^{*} \\
\mathrm{Nb} / \mathrm{Ta}\end{array}$ & $\begin{array}{l}0.7 \\
11\end{array}$ & $\begin{array}{c}0.6 \\
12\end{array}$ & $\begin{array}{l}0.7 \\
10\end{array}$ & $\begin{array}{l}0.7 \\
12\end{array}$ & $\begin{array}{c}0.72 \\
13.81\end{array}$ & $\begin{array}{l}0.79 \\
12.1\end{array}$ & $\begin{array}{c}0.72 \\
12\end{array}$ & $\begin{array}{l}0.66 \\
11.9\end{array}$ & $\begin{array}{l}0.67 \\
10.9\end{array}$ & $\begin{array}{l}0.67 \\
10.3\end{array}$ \\
\hline $\mathrm{K}_{2} \mathrm{O} / \mathrm{Na}_{2} \mathrm{O}$ & 1.2 & 1.2 & 1.1 & 1.1 & 1.12 & 1.09 & 1.3 & 1.12 & 1.22 & 1.2 \\
\hline $\mathrm{Mg \#}$ & 0.4 & 0.4 & 0.4 & 0.4 & 0.42 & 0.43 & 0.41 & 0.42 & 0.42 & 0.41 \\
\hline
\end{tabular}



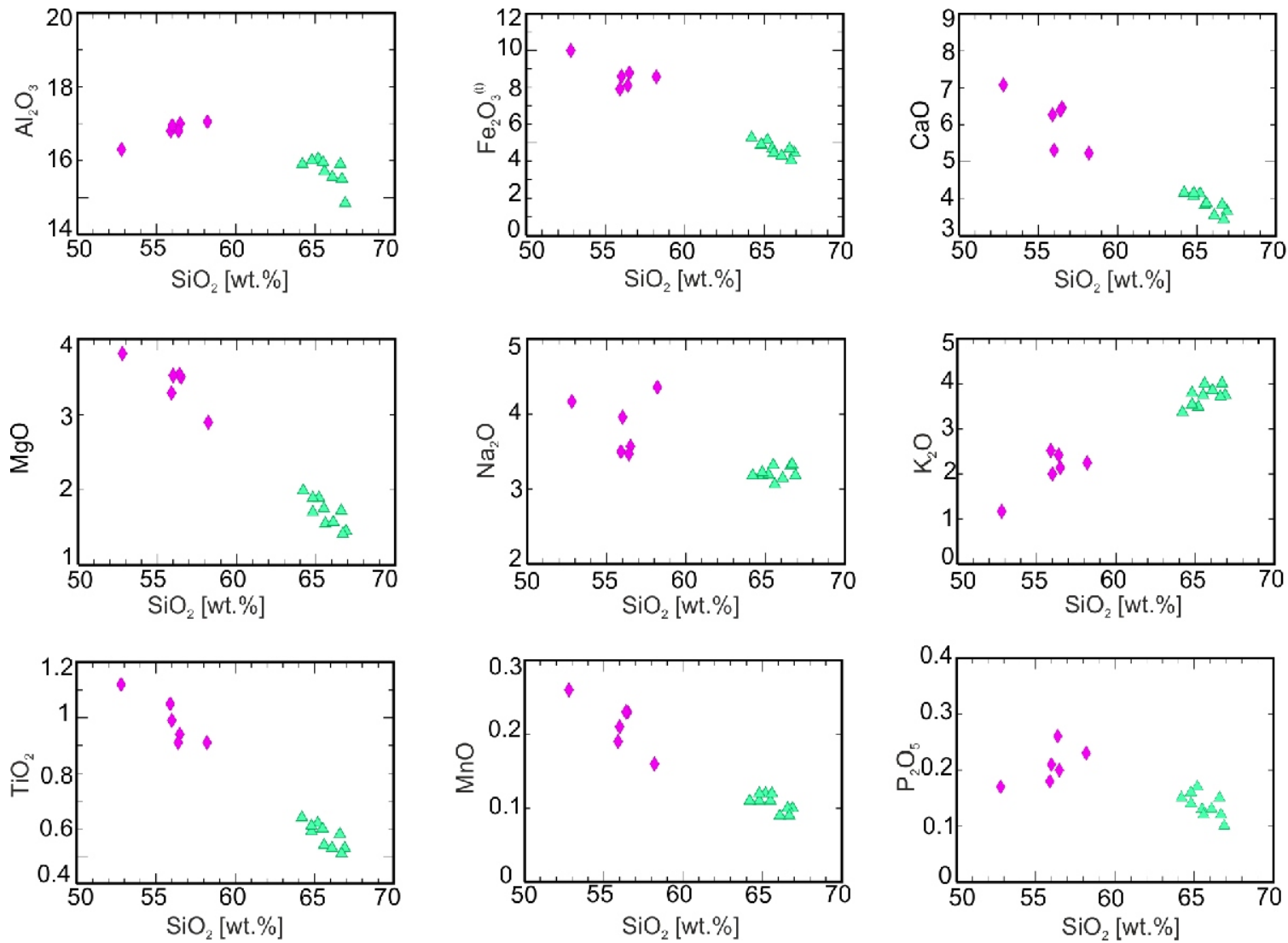

Fig. 5. Hacker plots of major elements for the DBG and their MMEs

minous (Fig. 4B). Granodiorites have a restricted range of $\mathrm{SiO}_{2}$ (64.2-66.9), $\quad \mathrm{Al}_{2} \mathrm{O}_{3} \quad$ (14.8-16), $\quad \mathrm{Fe}_{2} \mathrm{O}_{3}{ }^{(\mathrm{t})}$ (4-5.26), $\quad \mathrm{CaO}$ (3.44-4.16), $\mathrm{MgO}$ (1.41-1.99), $\mathrm{K}_{2} \mathrm{O}$ (3.44-4.16) and $\mathrm{TiO}_{2}$ (0.51-0.69). The DBG rocks are calc-alkaline and enriched in potassium as seen on a $\mathrm{K}_{2} \mathrm{O}+\mathrm{Na}_{2} \mathrm{O}+\mathrm{CaO}$ against $\mathrm{SiO}_{2}$ diagram (Frost et al., 2001; Fig. 4C). On a total alkali against $\mathrm{SiO}_{2}$ classification plot, the MMEs are situated in the field of diorite and quartz-monzodiorite (Fig. 4A) and have intermediate-mafic signatures $\left(\mathrm{SiO}_{2}=52.8-58.2\right)$. Harker plots of some major and trace elements display trends with a compositional gap between the host granodiorites and MMEs. The MMEs have higher contents of $\mathrm{Al}_{2} \mathrm{O}_{3}$ (16.3-17), $\mathrm{Fe}_{2} \mathrm{O}_{3}{ }^{(\mathrm{t})}$ (7.9-9.99), $\mathrm{CaO}$ (5.2-7), $\mathrm{MgO}$ (2.9-3.81), $\mathrm{TiO}_{2}(0.91-1.12)$ and $\mathrm{P}_{2} \mathrm{O}_{5}$ $(0.17-0.26)$ as well as lower concentrations of $\mathrm{K}_{2} \mathrm{O}(1.17-2.52)$ in comparison with the host granodiorites (Figs. 4C and 5). The contents of $\mathrm{Nb}, \mathrm{Y}, \mathrm{Sr}$, and $\mathrm{V}$ in the MMEs is higher than those of the host rocks (Fig. 6). Non-linear trends can be formed for some trace elements by chaotic movement (Perugini et al., 2008; Słaby et al., 2011).

On a chondrite-normalized REE diagram (Boynton, 1984), both of the host granodiorites and the MMEs show moderately concave-upward patterns, with enrichment in $\mathrm{LREE}_{\mathrm{s}}$, a flat or non-fractionated pattern for the HREE segment and moderate Eu negative anomalies. It is noteworthy to mention that, MMEs are characterized by $(\mathrm{La} / \mathrm{Yb}) \mathrm{n}=4.8-7, \mathrm{Eu} / \mathrm{Eu}^{*}=0.44-0.7$ and all the MMEs samples display similar moderate total REE concentrations (163.8). ( $\mathrm{La} / \mathrm{Yb}) \mathrm{n}, \mathrm{Eu} / \mathrm{Eu}^{*}$ ratios and $\mathrm{REE}_{(\mathrm{t})}$ content of the host samples ranges from 7.13 to $10.7,0.6$ to 7.9 and 133.21 respectively (Fig. 7A).

In tprimitive mantle-normalized trace element patterns (Sun and McDonough, 1989), the granodiorites and the MMEs are generally enriched in large-ion lithophile elements (LILE) and depleted in high-field strength elements (HFSE). The granodiorites show negative $\mathrm{Nb}, \mathrm{Ti}, \mathrm{P}$ and $\mathrm{Ba}$ anomalies whereas enclaves display a special pattern; they have higher $\mathrm{Yb}, \mathrm{Y}, \mathrm{Dy}, \mathrm{Lu}, \mathrm{Sm}, \mathrm{Ti}, \mathrm{P}, \mathrm{Nb}$ and lower $\mathrm{Ba}$ and $\mathrm{Zr}$ amounts than those of their host rocks (Fig. 7B).

\section{MAGMA MIXING/MINGLING EVIDENCE}

Several lines of evidence document evaluate the possibility of source mixing/mingling in the Dehe-Bala MMEs:

\section{TEXTURAL FEATURES}

Based on field observations as described above, MMEs in the DBG exhibit generally ellipsoidal and rounded shapes ranging from 2 to $30 \mathrm{~cm}$ in size. Moreover, there is an absence of complex shapes, implying that magma mixing/mingling has been relatively weak in the MMEs (Barbarin, 2005; Farner et al., 2014). Certain disequilibrium textures are documented in the DBG, including poikilitic large feldspars, small lath-shaped plagioclase in large plagioclase, mafic clots, plagioclase with sieve texture, complex oscillatory zoning, repeated resorption surfaces in both the MMEs and host granodiorites, and also acicular apatite and quartz phenocrysts in the Dehe-Bala MMEs. These textural features are considered to reflect chemical and/or thermal changes in magma conditions, also supporting a magma mixing/mingling origin (Baxter and Feely, 2002).

The fine-grained texture of MMEs along with the existence of acicular apatite, the chilled margins and zoning in plagioclase most likely result from rapid temperature equilibration between the hotter mafic and cooler felsic magmas during magma mixing/mingling (Barbarin, 1990). According to Kumar (2010), the 

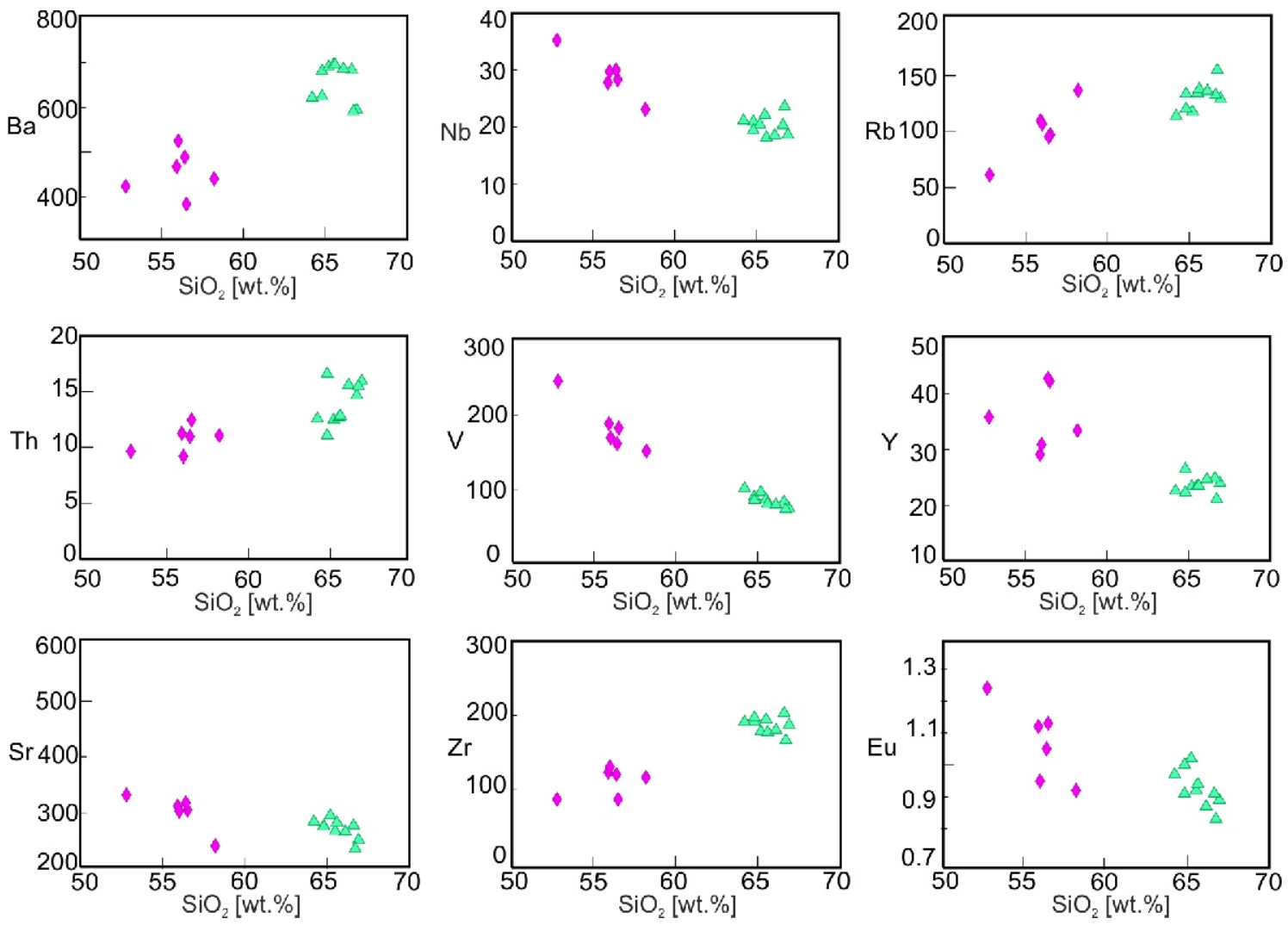

Fig. 6. Hacker plots of trace elements for the DBG and their MMEs
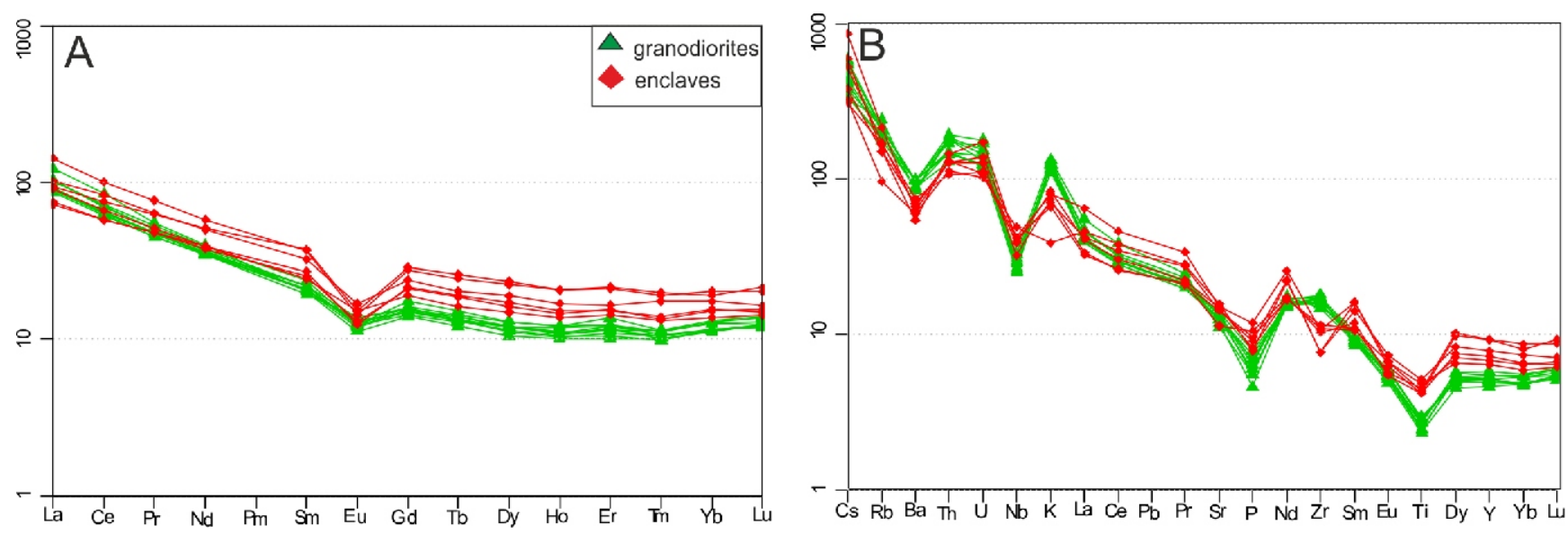

Fig. 7. The patterns of trace element distributions in DBG and the MMEs

A - chondrite-normalized REE patterns (Boynton, 1984);

B - primitive mantle-normalized trace element patterns (Sun and McDonough, 1989) 
mixing of cool and water-bearing felsic magma with dry and hot mafic magma can produce a variety of vapor phases which boosts the crystallization of hydrous phases (amphibole and biotite) at the expense of pyroxene. The presence of some remnants of pyroxene in the Dehe-Bala MMEs suggests that diffusion of water during magma mixing/mingling has been effective. The quartz ocelli and K-feldspar megacrysts in the MMEs most likely were entrained from the host to the MMEs in a magmatic environment (Bussy and Ayrton, 1990). In addition, the alignment of some minerals along the enclave-host boundaries suggest a magmatic origin for the Dehe-Bala MMEs. In turn, these textural features are regarded as evidence of the magma mixing /mingling process for the genesis of the DBG. The higher contents of $\mathrm{CaO}, \mathrm{MgO}$ and $\mathrm{Fe}_{2} \mathrm{O}_{3}{ }^{(\mathrm{t})}$ corresponding to a greater number of mafic minerals in the MMEs, suggest that they are derived from hotter and relatively more mafic melts than the host rocks (Kumar and Pieru, 2010).

\section{DIFFUSION AND CHEMICAL EXCHANGE}

Best (1982) highlighted that diffusion of atoms or molecules is a spontaneous process which occurs due to different concentrations of energy or composition in the solid, liquid and gas phases. There are two main diffusion processes in igneous systems as regards chemical exchange: (1) volatile and fluid migration from the felsic component to the mafic one (Vernon, 1983) that significantly enhances the rate of diffusion (Watson, 1981), (2) diffusion of elements resulting from thermal, mechanical and compositional contrasts between coeval felsic and mafic magma (Vogel et al., 1984). Major and trace elements are considered as network-forming and non-network components in silicate magmas, respectively. Therefore, trace elements display higher diffusional mobility relative to major elements during magma mixing/mingling events (Lesher, 1990). The major and trace element data of the DBG seemingly show element exchange which is mainly related to hybridization between the MMEs and the host granodiorites during magma mixing/mingling. As stated previously, the DBG and their MMEs are different in terms of their contents of some major elements. The trace elements of the MMEs and host granodiorites illustrate similar trends to primitive mantle-normalized patterns. In addition, the MMEs have similar REE patterns to those of the host rocks, but the MMEs have higher total REE and HREE concentrations. Higher HREE and total REE concentrations in the MMEs of the DBG may be the result of diffusion of elements from the host granodiorites to the magmatic enclaves during magma mixing/mingling. Furthermore, the REE enrichments are in accordance with crystallization of accessory minerals such as apatite, zircon and titanite in the MMEs (Sawka, 1988). Similarly, the higher $\mathrm{Al}_{2} \mathrm{O}_{3}, \mathrm{TiO}_{2}, \mathrm{MgO}$ and $\mathrm{FeO}_{3}{ }^{(\mathrm{t})}$ in the Dehe-Bala MMEs may be related to lower diffusional mobility from the MMEs to their felsic host. Therefore, these geochemical features are interpreted as being indicative of various diffusion rates and relative equilibration between mafic and felsic magmas from diverse sources during magma mixing/mingling (Kumar and Pieru, 2010).

In harker diagrams, a negative relationship between $\mathrm{SiO}_{2}$ and some major element oxides is observed $(\mathrm{CaO}, \mathrm{MgO}$, $\mathrm{Fe}_{2} \mathrm{O}_{3}, \mathrm{TiO}_{2}, \mathrm{P}_{2} \mathrm{O}_{5}$ and $\mathrm{MnO}$ ). According to the geochemical criteria three stages of hybridization have been proposed for the MMEs as shown below (Tindle, 1991):

1. MMEs with at least hybridization characterized by $\mathrm{SiO}_{2}$ less than 55 wt. \% (DA5 = 52.8).

2. MMEs with little hybridization characterized by $\mathrm{SiO}_{2}$ about 56 wt. $\%(\mathrm{DA} 1=56, \mathrm{DA} 40=56.5, \mathrm{DA} 41=56.4$, DA43 $=55.9)$
3. MMEs with moderate hybridization characterized by $\mathrm{SiO}_{2}$ close to 58 wt.\% (DA42 = 58.2).

The MMEs of stage 1 can be indicative of rapid undercooling of magmas, which most probably reflects the minimum degrees of magma mixing/mingling between MMEs and their felsic host rock magmas. The MMEs of 2 and 3 stage illustrate slower cooling of magmas, so the MME magmas show signs of slight chemical exchange with their host magmas. Overall, the geochemical data strongly suggests that the MMEs from the DBG have experienced low levels of hybridization with their felsic host rocks, like stage 2.

\section{FRACTAL DIMENSIONS OF MMES}

The MMEs contained in the DBG display rounded and ovoid forms, and also sharp and uneven contacts with their felsic host rocks. The MME shapes are dependent on linear or chaotic movement mainly due to interaction between coeval felsic and mafic magmas in the magma chamber (Vernon et al., 1988; Kumar et al., 2004).

When an object shows self-similar properties and an irregular shape, it is described as fractal. Fractal theory has been used for describing natural shapes. It is difficult to apply mathematical geometry to these kinds of irregular shapes in nature because they cannot be represented with Euclidean geometry. As noted by Mandelbrot (1989), self-similarity of fractals implies that patterns tend to repeat themselves at all scales, and for a true fractal, the number of scales of natural patterns is infinite.

In fact, the heterogeneity of the morphology of the MMEs is another natural expression of self-similar patterns which can be measured as fractal structures (Perugini and Poli, 2000). Photographs of 24 samples were taken for accurate detection of the contact between the MMEs and the corresponding felsic granodiorites. Several photos of the interface were taken to evaluate the error, which was considered to be about $2-3 \%$. The photos were converted to binary images by use of software ImageJ. In binary images, the MMEs and the host are separated from each other by black and white pixels, respectively. The fractal patterns from the Dehe-Bala MMEs were calculated by a box-counting method $\left(D_{\text {box }}\right)$ and by the following relationship (Mandelbrot, 1982) in the software Image J:

$$
\log (N)=-D_{b o x}+\log (r)
$$

According to equation [1] the fractal dimension is a function of the number of boxes $(N)$ with different sizes $(r)$ that contain part of the image.

The slope of the line in a plot of $\log (r)$ vs. $\log (N)$ is equal to $-D_{\text {box }}$. The $D_{\text {box }}$ value in the 24 samples from the Dehe-Bala MMEs varies from 1.14 to 1.29 (Table 3 ) and has a mode of $D_{\text {box }}=1.29$ in the histogram (Fig. 8).

\section{VISCOSITY}

Perugini and Poli (2005) proposed that the fractal dimensions of the contact surface between two fluids $\left(D_{\text {box }}\right)$ and their viscosity ratio $(V R)$ are strictly related (Table 3$)$. After many experiments they extracted a new empirical equation as follows:

$$
\log (V R)=0.013 \times e^{3.34 \times D_{\text {box }}}
$$

In this part, we estimate the logarithm of the viscosity ratio according to eqation [2] and the $D_{b o x}$ values. The logarithm of the viscosity ratio $\log (V R)$ varies between 0.56 to 0.96 and Figure 9 depicts the highest frequency as about 0.96 . 
The results of fractal dimensions of MMEs $\left(D_{\text {box }}\right)$ and logarithm of the viscosity ratio between the granodiorites and the MMEs

\begin{tabular}{|c|r|r|r|r|r|r|r|r|r|r|c|}
\hline sample & \multicolumn{1}{|c|}{ C2 } & \multicolumn{1}{c|}{ C3 } & \multicolumn{1}{c|}{ C4 } & \multicolumn{1}{c|}{ C6 } & \multicolumn{1}{c|}{ 8 } & C12 & C16 & C32 & C64 & $D_{\text {box }}$ & $\log (V R)$ \\
\hline 1 & 1530 & 944 & 679 & 412 & 296 & 179 & 128 & 52 & 22 & 1.224 & 0.77 \\
\hline 2 & 935 & 538 & 395 & 225 & 162 & 99 & 68 & 31 & 14 & 1.212 & 0.74 \\
\hline 3 & 5239 & 3223 & 2247 & 1401 & 954 & 569 & 390 & 159 & 60 & 1.286 & 0.95 \\
\hline 4 & 632 & 412 & 281 & 180 & 131 & 81 & 56 & 23 & 11 & 1.183 & 0.67 \\
\hline 5 & 901 & 552 & 376 & 218 & 159 & 93 & 66 & 27 & 12 & 1.254 & 0.85 \\
\hline 6 & 1645 & 1024 & 698 & 416 & 287 & 173 & 122 & 54 & 25 & 1.221 & 0.76 \\
\hline 7 & 2486 & 1456 & 999 & 588 & 400 & 240 & 173 & 72 & 30 & 1.271 & 0.9 \\
\hline 8 & 2154 & 1268 & 891 & 535 & 370 & 210 & 156 & 61 & 24 & 1.292 & 0.97 \\
\hline 9 & 2122 & 1244 & 880 & 510 & 348 & 205 & 143 & 60 & 24 & 1.292 & 0.97 \\
\hline 10 & 3655 & 2251 & 1539 & 947 & 623 & 388 & 250 & 105 & 47 & 1.272 & 0.9 \\
\hline 11 & 3598 & 2168 & 1487 & 883 & 604 & 363 & 245 & 103 & 45 & 1.273 & 0.91 \\
\hline 12 & 4281 & 2602 & 1825 & 1080 & 730 & 432 & 293 & 120 & 49 & 1.297 & 0.98 \\
\hline 13 & 1432 & 894 & 643 & 374 & 273 & 161 & 114 & 50 & 21 & 1.222 & 0.77 \\
\hline 14 & 1066 & 635 & 453 & 280 & 202 & 123 & 85 & 39 & 17 & 1.19 & 0.69 \\
\hline 15 & 1243 & 722 & 483 & 279 & 197 & 111 & 85 & 38 & 15 & 1.261 & 0.87 \\
\hline 16 & 1724 & 1022 & 705 & 415 & 288 & 173 & 115 & 48 & 20 & 1.289 & 0.96 \\
\hline 17 & 1744 & 1059 & 746 & 441 & 307 & 185 & 130 & 53 & 26 & 1.231 & 0.79 \\
\hline 18 & 5048 & 2889 & 2006 & 1146 & 788 & 465 & 336 & 148 & 57 & 1.28 & 0.93 \\
\hline 19 & 826 & 505 & 342 & 205 & 141 & 84 & 62 & 27 & 10 & 1.26 & 0.87 \\
\hline 20 & 3462 & 2100 & 1474 & 946 & 678 & 417 & 283 & 118 & 49 & 1.223 & 0.77 \\
\hline 21 & 755 & 462 & 320 & 209 & 144 & 88 & 69 & 28 & 12 & 1.186 & 0.68 \\
\hline 22 & 934 & 552 & 379 & 238 & 163 & 96 & 71 & 32 & 12 & 1.238 & 0.81 \\
\hline 23 & 857 & 515 & 381 & 237 & 161 & 110 & 70 & 33 & 17 & 1.144 & 0.59 \\
\hline 24 & 1099 & 684 & 499 & 311 & 216 & 138 & 97 & 47 & 22 & 1.133 & 0.57 \\
\hline
\end{tabular}

C2-C64 values introduce box sequences with different sizes

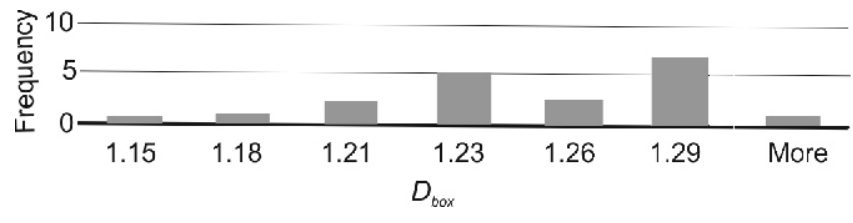

Fig. 8. Frequency histogram representing the distribution of values of the fractal dimensions $\left(D_{b o x}\right)$ of the MMEs in the DBG

Furthermore, a melt viscosity model (Giordano et al., 2008) as a function of whole-rock geochemical composition and temperature was applied to estimate the viscosity of the enclave and host granodiorite samples. The melt viscosities for melts with $2.5,2$ and 1 wt. $\%$ of $\mathrm{H}_{2} \mathrm{O}$ at different temperatures were determined (Table 4) using PELE software (Boudreau, 1999). The average whole-rock composition was recalculated to 100 after adding 2.5, 2 and 1 wt. $\% \mathrm{H}_{2} \mathrm{O}$.

\section{DISCUSSION}

\section{GEOCHEMICAL INTERPRETATION}

DBG

The relatively high concentrations of $\mathrm{SiO}_{2}(64.2-66.9), \mathrm{K}_{2} \mathrm{O}$ (3.44-4.16) and metaluminous nature accompanied by several mineralogical features including the presence of hornblende

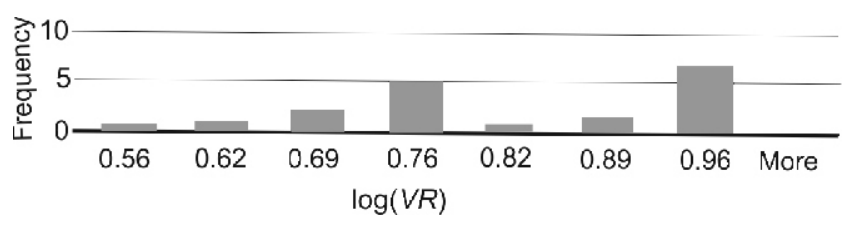

Fig. 9. Frequency histogram representing the distribution of values of logarithm of the viscosity ratio $\log (V R)$ between the granodiorite host and the MMEs

and the lack of cordierite, garnet, and normative corundum demonstrate that the DBG belong to I-type granites.

In comparison with melts produced by experimental dehydration-melting (Patiño Douce, 1999), the composition of DBG rocks indicate an igneous source. Some elemental ratios such as high $\mathrm{CaO} / \mathrm{Na}_{2} \mathrm{O}>1$, molar $\mathrm{CaO} / \mathrm{MgO}+\mathrm{FeO}^{(\mathrm{t})}>0.5$ values and small proportions of $\mathrm{Al}_{2} \mathrm{O}_{3} / \mathrm{TiO}_{2}(<35), \mathrm{Rb} / \mathrm{Ba}(<1), \mathrm{Rb} / \mathrm{Sr}$ $(<1)$ as well as the molar $\mathrm{Al}_{2} \mathrm{O}_{3} / \mathrm{MgO}+\mathrm{FeO}^{(t)}(<2)$ support their derivation from basaltic amphibolite sources (Fig. 10A, B).

Moreover, it is notable that the DBG have higher $M g \neq$ (0.39-0.43) levels than that of experimentally yielded pure crustal partial melts as depicted in Figure 3. However, the high $\mathrm{Mg} \neq$ value of the samples studied is in conflict with adakitic magmas because of the fact that these rocks have lower $\mathrm{Sr} / \mathrm{Y}$ $(=10.41-12.6)$ and $(\mathrm{La} / \mathrm{Yb})_{\mathrm{n}}=7.13-10.7$ ratios than those in adakites. Common adakite magmas are characterized by $\mathrm{Sr} / \mathrm{Y}>40$ and $(\mathrm{La} / \mathrm{Yb})_{n}>12$ ratios (Wang et al., 2005; Fig. 10C).

Furthermore, The $\mathrm{Ba} / \mathrm{Rb}$ ratio in the Dehe-Bala I-type granodiorites $(\mathrm{Ba} / \mathrm{Rb}=3.81-5.84, \approx 5)$ is lower than in man- 
T a ble 4

The viscosity calculations of samples in the DBG (DG9) and their enclaves (DA5 and DA42) at different temperatures and $\mathrm{H}_{2} \mathrm{O}$ content (using PELE software Boudreau, 1999 and equations of Giordano et al., 2008)

\begin{tabular}{|r|c|c|c|c|c|c|c|c|c|}
\hline & \multicolumn{5}{|c|}{ DG9 } & \multicolumn{3}{c|}{ DA5 } & \multicolumn{3}{c|}{} \\
\hline $\begin{array}{c}\text { wt. } \% \\
\mathrm{H}_{2} \mathrm{O}\end{array}$ & 2.5 & 2 & 1 & 2.5 & 2 & 1 & 2.5 & 2 & 1 \\
\hline \multicolumn{7}{|c|}{$T\left[{ }^{\circ} \mathrm{C}\right]$} \\
\hline 1000 & 4.6 & 4.8 & 5.6 & 3.6 & 3.8 & 4.5 & 4.0 & 4.2 & 4.9 \\
\hline 900 & 6.0 & 6.3 & 7.2 & 5.1 & 5.5 & 6.3 & 5.4 & 5.8 & 6.6 \\
\hline 800 & 7.3 & 7.7 & 8.8 & 6.5 & 6.9 & 7.9 & 6.8 & 7.2 & 8.2 \\
\hline 700 & 8.7 & 9.2 & 10.6 & 7.9 & 8.3 & 9.5 & 8.2 & 8.6 & 9.8 \\
\hline 600 & 10.4 & 11 & 12.7 & 9.4 & 9.9 & 11.3 & 9.7 & 10.3 & 11.7 \\
\hline
\end{tabular}
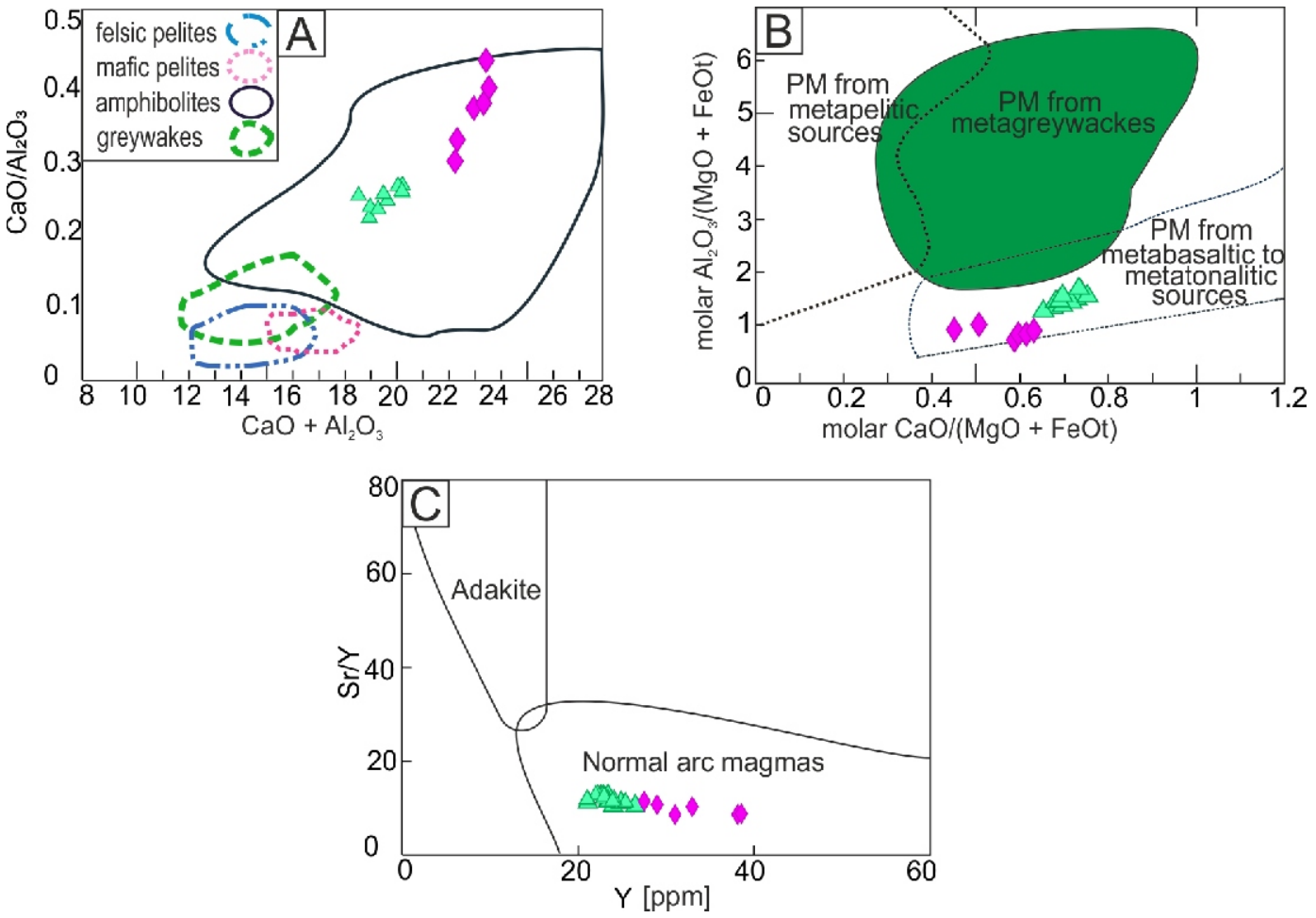

Fig. 10A, B - the comparison between the Dehe-Bala samples with experiments obtained from partial melting of the crust and mantle rocks in the absence of fluid (Patiño Douce, 1999); C - Sr/Y vs. Y (Drummond and Defant, 1990) diagram for the Dehe-Bala samples

tle-derived magmas $(\mathrm{Ba} / \mathrm{Rb}=11$; Hofmann and White, 1983) and it is closer to that of crustal-derived magmas $(\mathrm{Ba} / \mathrm{Rb}=6.7)$ (Rudnick and Fountain, 1995). Also the Th/Ta ratio, which is an important characteristic of crust-mantle interaction, is about 2 for mantle-derived rocks, 6.9 for upper crust and 7.9 for lower crust (Shellnutt et al., 2009). The $\mathrm{Th} / \mathrm{Ta}$ ratio in granodiorites $(\mathrm{Th} / \mathrm{Ta}=6.22-9.35, \approx 7.9)$ is consistent with participation of lower crust in the formation of the granodiorite magma (Shellnutt et al., 2009). The $\mathrm{Nb} / \mathrm{Ta}$ ratios in the DBG vary from 10 to 13.81. Mantle-derived melts are generally characterized by a high $\mathrm{Nb} / \mathrm{Ta}$ ratio (>17.5; Huang et al., 2011), the $\mathrm{Nb} / \mathrm{Ta}$ ratio of crustal-derived melts ranging from 10 to 13.8 (Rudnick and Fountain, 1995; Huang et al., 2011). Thus they cannot be considered pure melt derivatives from crust. The mixture of crust-derived felsic with mantle-derived mafic melts is a suitable explanation for the origin of the DBG. The REE plots of the granodiorite samples display moderately fractionated REE Patterns $\left((\mathrm{La} / \mathrm{Yb})_{\mathrm{n}}=7.13-10.7\right)$, enrichment in LREEs $\left((\mathrm{La} / \mathrm{Sm})_{\mathrm{n}}=\right.$ 4-6.2) and relative depletion in HREEs $\left((\mathrm{Gd} / \mathrm{Yb})_{n}=1.19-1.38\right)$. The flat patterns for HREE and relatively high Y contents suggest that the melting of sources occurred outside the garnet stability field (Rapp and Watson, 1995). The moderately fractionated REE patterns $\left((\mathrm{La} / \mathrm{Yb})_{\mathrm{n}}=7.13-10.7\right)$ and the high $\mathrm{Y} / \mathrm{Yb}=8.79-10$ and low $(\mathrm{Ho} / \mathrm{Yb})_{\mathrm{n}}=0.87-0$ ratios can be attributed to an amphibole-bearing source (Hu et al., 2012).

Harker plots of selected major and trace elements show systematic variations in elemental concentration. A prominent feature of the fractional crystallization pattern is depicted in the 

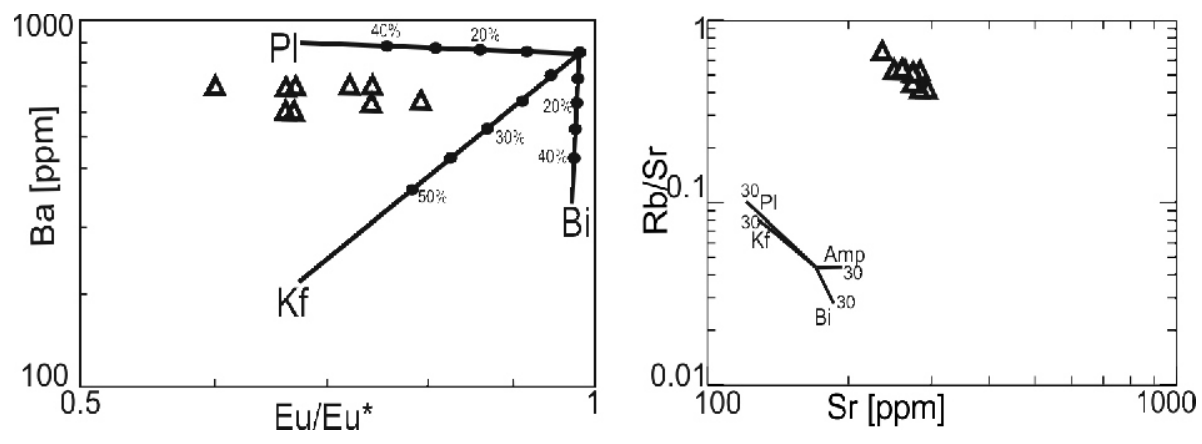

Fig. 11. A prominent feature of fractional crystallization pattern in the Ba vs. Eu/Eu* and $\mathrm{Rb} / \mathrm{Sr}$ vs. Sr plots for DBG samples

$\mathrm{Ba}$ vs. $\mathrm{Eu} / \mathrm{Eu}^{*}$ and $\mathrm{Rb} / \mathrm{Sr}$ vs. Sr diagrams (Fig. 11). With increase in $\mathrm{SiO}_{2}$, the amounts of $\mathrm{MgO}, \mathrm{CaO}, \mathrm{Al}_{2} \mathrm{O}_{3}, \mathrm{Fe}_{2} \mathrm{O}_{3}{ }^{\left({ }^{(t)}\right.}, \mathrm{Sr}$, $\mathrm{Eu} / \mathrm{Eu}^{*}$ decrease, while $\mathrm{K}_{2} \mathrm{O}, \mathrm{ASI}$ and $\mathrm{Ba}$ increase. These variations imply that fractional crystallization of plagioclase and hornblende is dominant during magma evolution (Wilson, 1989). The moderate $\mathrm{Rb} / \mathrm{Ba}$ and $\mathrm{Rb} / \mathrm{Sr}$ ratios suggest lower degrees of fractionation in I-type granitoids (Landenberger and Collins, 1996). These ratios in the DBG show that the granodiorites are not highly fractionated granites ( $\mathrm{Rb} / \mathrm{Ba}$ (0.17-0.26) and $\mathrm{Rb} / \mathrm{Sr}(0.4-0.65)$. Geochemical data suggest that the evolution of the granodiorites was controlled by fractional crystallization and magma mixing processes in the Dehe-Bala suite. According to the whole-rock geochemistry and field relations it seems that the DBG composition is a mixture of crust and mantle magmas along with stronger crustal contribution while, on the other hand, the potassic content of samples $\left(\mathrm{K}_{2} \mathrm{O} / \mathrm{Na}_{2} \mathrm{O}=1.16\right)$, the LILE enrichment relative to the $\mathrm{HFSE}$ as well as the negative $\mathrm{Ba}$ anomalies and the $\mathrm{Th} / \mathrm{Ta} \approx 7.9$ ratio show that lower continental crust (LCC) has played an important role in the origin of the DBG. Evidently, mantle-derived mafic magma injection beneath the lower crust led to heat transfer and chemical exchange between coeval felsic and mafic magmas (Hildreth and Moorbath, 1988, Kananian et al., 2014). Therefore, we can conclude that most likely parental magma of these rocks was derived from the partial melting of mafic lower crust and then mixed to a low degree with mantle-derived mafic magma.

MMEs

The origin of MMEs has long been controversial. The MMEs in the DBG are regarded as testimonies of mantle-derived mafic magma which can also serve as a document of incomplete mixing between two distinct magmas. The MMEs and the host granodiorites display similar mineral assemblages with igneous textures, which is inconsistent with the restite model. Metamorphic or residual sedimentary fabric is one of the features of the restite model (White et al., 1999). Also, the lack of cumulate textures and the presence of chilled margins in the MMEs is inconsistent with the autolith model. It is also noteworthy that the relatively similar content of REEs, semi-parallel trace element patterns and grain size difference between the MMEs and their host granodiorites, strongly contra-indicate an autolith origin for MMEs formation. The $\mathrm{Mg} \neq 0.4-0.46$ value in the MMEs is slightly higher than that in the host granodiorites $(\mathrm{Mg} \neq 0.39-0.43)$, which supports the probability mixing/mingling of mantle-derived mafic magma with crust-derived felsic magmas in various proportions.
The average $\mathrm{Nb} / \mathrm{T}$ a ratio in crust-derived melts is about 11 to 12 and in mantle-derived melts is 17.5 (Green, 1995). This ratio in the MMEs is 15.44 . As noted by Morata et al. (2005), the $\mathrm{La} / \mathrm{Nb}$ and $\mathrm{Ba} / \mathrm{Nb}$ ratios for crust-derived melts are 2.2 and 5.4 and for mantle-derived melts vary between 0.76-1.03 and 7.6-17.4, respectively. The $\mathrm{La} / \mathrm{Nb}$ and $\mathrm{Ba} / \mathrm{Nb}$ ratios of the Dehe-Bala MMEs range from 0.7 to 1.4 and 12 to 19 , respectively. These elemental ratios suggest significant contribution of a more mafic magmatic component in the genesis of these MMEs. Partial melting in the garnet stability field produces melts with high values of the $(D Y / Y b>2.5)$ ratio, whereas mantle-derived melts in the spinel field have generally lower ratios of DY/Yb < 1.5 (Liu et al., 2015). Moreover, the Dehe-Bala MMEs are characterized by $\mathrm{Dy} / \mathrm{Yb}$ ratios of about 2 and relatively potassic contents of $\mathrm{K}_{2} \mathrm{O}=1.4-3.8$, implying that enclave-forming magmas derived from partial melting of mantle in the spinel-garnet transition zone. These observations lead us to conclude that the MMEs in the DBG were globules of mantle-derived mafic magma. Mafic globules were injected into crust-derived felsic magma and partially mixed with host magma.

TRACING MAGMA MIXING

Field observations and geochemical data illustrate that magma mixing has occurred in the Dehe-Bala complex. In order to know what fraction of mafic magma is present in the granodiorites and the enclaves, we have chosen two representative enclave and granodiorite samples (DA1 and DG9) with low, and high $\mathrm{SiO}_{2}$ content respectively to calculate the amount of mixing using the following mixing equation (Fourcade and Allègre, 1981):

$$
\operatorname{CiM}-\mathrm{CiA}=X(\mathrm{CiB}-\mathrm{CiA})
$$

$\mathrm{CiA}$ is the concentration of element $i$ in the felsic end-member (i.e. the average composition of granodiorites as the felsic end-member), $C i B$ is a component which shows the concentration of element $i$ in the mafic end-member (i.e. the DA5 sample and the average composition of the enclaves were calculated as the mafic end-member in the enclaves and granodiorites respectively), the last component is CiM which shows the concentration of element $i$ in hybrid magmas (i.e. DA1 and DG9). $X$ is the fraction of mafic component in the hybrid.

The plot of mixing parameters shows slopes $(x)$ of 0.98 and 0.13 for DA1 and DG9 samples respectively (Fig. 12). It seems that the hybrid enclaves and granodiorites were generated by a minimum degree of mixing of felsic and mafic end-members 
A

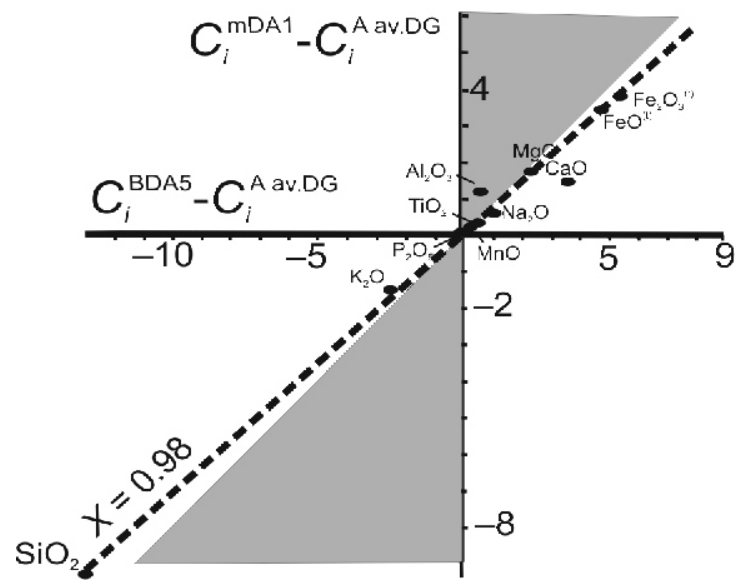

B

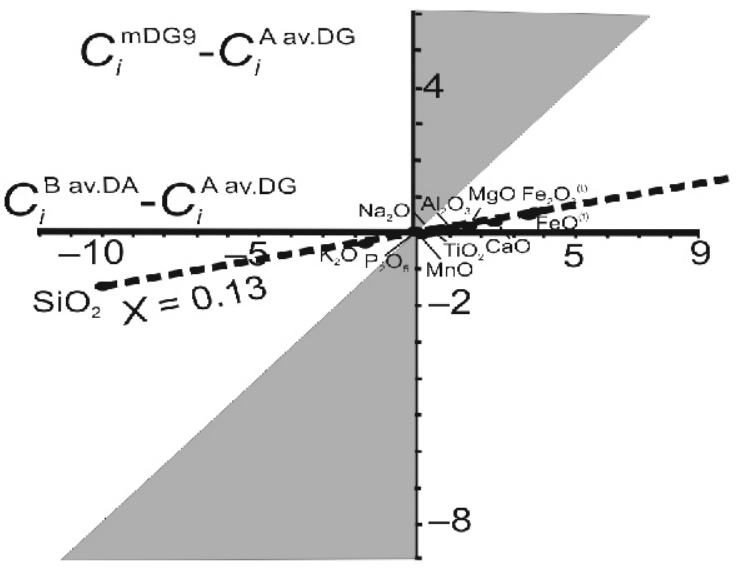

Fig. 12. Magma mixing plots (CiM-CiA versus CiB-CiA) using major elements for A - DA1 and B - DG9 samples

Magma mixing process is not occurred in the grey area (after Fourcade and Allégre, 1981); see text for more discussion

with a relatively high mafic mass fraction in the enclaves and a low fraction in the granodiorites.

Perugini and Poli (2000) suggested that the fractal dimensions of MMEs are related to the different degrees of magmatic interaction. Thus, with decreasing of fractal dimensions within MMEs, the morphology of the interface between coeval felsic and mafic magmas probably become less complex, and so MMEs reflect increasing "dilution" with felsic magma and lie farther away from the mafic end-member in composition. In the contrast, as the fractal dimensions of MMEs increase, the interface becomes more irregular, hence these MMEs display lower degrees of contamination and are more similar to the mafic end-member (Perugini and Poli, 2000; Albert et al., 2014). As shown in Figure 13 the $D_{b o x}$ values decrease from $\mathrm{A}$ to $\mathrm{C}$ and also from $\mathrm{D}$ to $\mathrm{F}$. The decrease in the $D_{b o x}$ value is accompanied by reducing the complexity of the morphology of the MMEs. Figure 14 emphasizes that different $D_{\text {box }}$ values correspond to different $\log (V R)$.

When the $\log (V R)$ decreases, the mixing process is facilitated between coeval felsic and magmas; consequently, the MMEs display lower $D_{\text {box }}$ and are closer in composition to the mafic end-member. Field and petrography relations of mixing structures show that both magmas behaved as liquids at the same time. The presence of plagioclase phenocrysts at the interface implies that there was a small viscosity difference between two magmas (Chen et al., 2009). Furthermore, the viscosity calculations indicates logngr $>\log$ nen at different temperatures and also a small viscosity difference between the enclave and granodiorite melts (Fig. 15 and Table 4). This suggests that the proportion of mafic magma may have been large enough $(>80 \%$; Laumonier et al., 2014) to heat the felsic magma to lower the mixing degree between two coeval magmas. Comparison of the viscosities of the granodiorites and the enclaves suggest that when the high temperature mafic magma encountered the felsic magma with lower temperature and higher water content, the mafic magma dropped in temperature and the temperature of the felsic magma started to increase (Grove and Sando, 1982; Hildreth and Moorbath, 1988), therefore $\log (V R)$ decreases and magma mixing processes were easier. At the same time the mafic magma cooled off and crystallized to generate more viscous enclaves. Thus, the viscosity values of the magmas could be reversed (lognen $>$ logngr). The enclaves in the Dehe-Bala granodiorites have higher $D_{b o x}$ and $\log (V R)$. They were also closer in composition to the mafic end-member. The viscosity of DA42 was higher than that of DA1 because of the fact that the DA42 sample is more evolved than DA1 and produced by moderate hybridization with the felsic magma. This is consistent with the geochemical data and the fractal dimensions of enclaves $\left(D_{\text {box }}\right)$ in the Dehe-Bala complex.

\section{CONCLUSION}

Based on the geochemical results presented in this research, we can conclude that:

1. The Dehe-Bala granodiorites are high- $\mathrm{K}$ calc-alkaline, metaluminous and display geochemical characteristics of l-type granites. The negative $\mathrm{Nb}$ and $\mathrm{Ti}$ anomalies and low $\mathrm{Sr}$ (236-296) and high Y (21-26.5) contents along with negative Eu anomalies, the flat pattern in HREE and moderately fractionated REE patterns of the chondrite-normalized REE plots in the studied samples implies to a garnet-free source.

2. The granodiorite rocks have been derived by partial melting of lower crust rocks, then experienced low degrees of mixing/mingling with mantle-derived mafic magma. Similarly, MMEs from the DBG show signs of a magma mixing/mingling origin as attested by the high contribution of a mantle component and a low proportion of the felsic component in their evolution.

3. The distribution of major and trace elements along with the occurrence of some crystals belonging to the felsic host (e.g. K-feldspar megacrysts and quartz ocelli) within enclaves can be regarded as reflecting chemical exchange and diffusional processes that may be considered as a natural result of the magma mixing/mingling event.

4. The textural heterogeneity related to the Dehe-Bala MMEs has been determined as of high fractal dimension $\left(D_{\text {box }}=1.29\right)$. Thus fractal study of MMEs provided a different and new perspective on the Dehe-Bala complex. The first result of the fractal analysis is that the MMEs with high $D_{\text {box }}$ values have more complexity of morphology among the MMEs. The second outcome is that the MMEs with high $D_{\text {box }}$ values display high log VR and hence reflect low degrees of mixing/mingling with the host magma. Finally, lower degrees of mixing/mingling have been demonstrated in the Dehe-Bala complex, both from the geochemical and the fractal geometry points of view. 

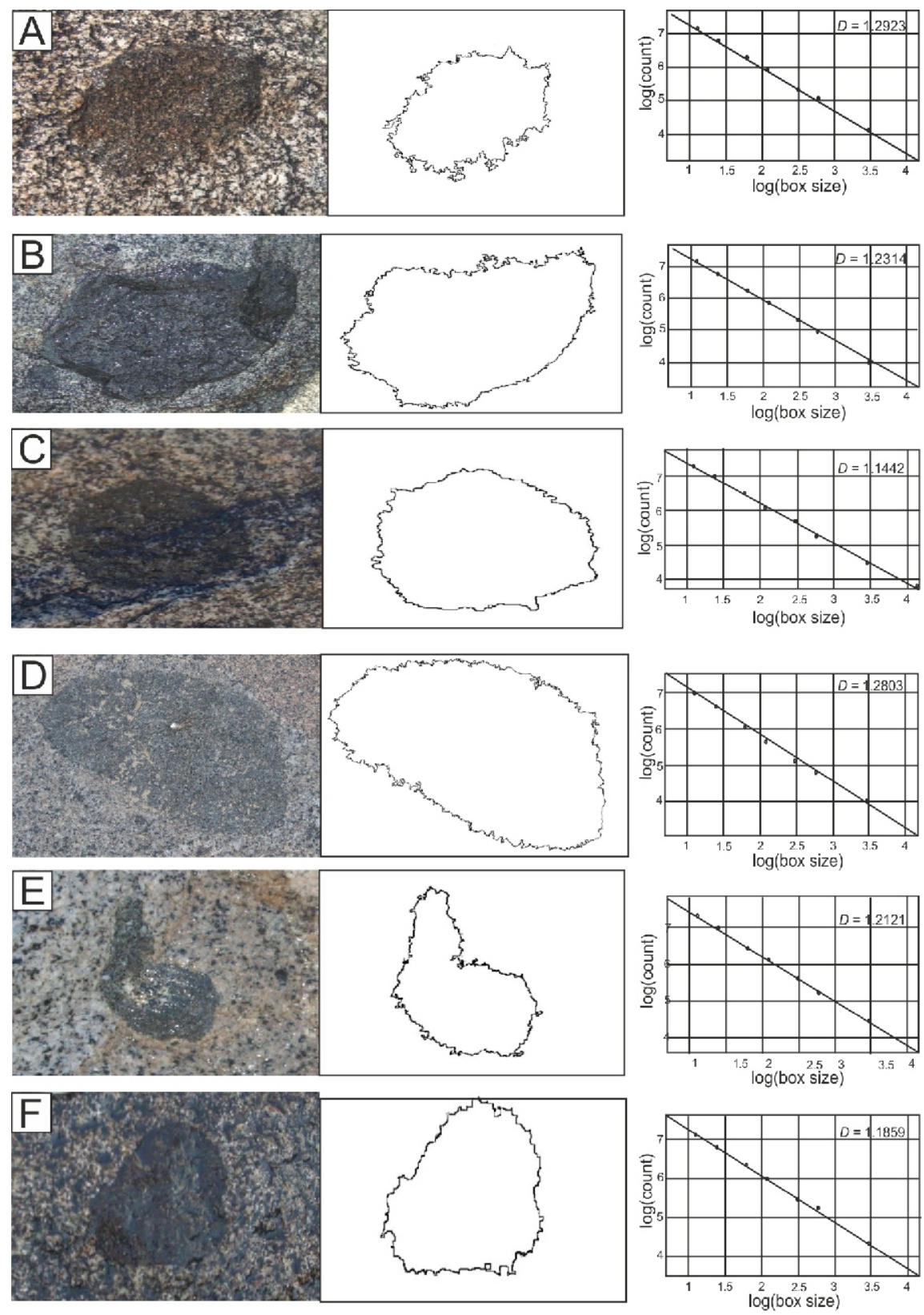

Fig. 13. Examples of fractal dimensions of the boundary between the enclaves with granodiorite host. The images and the diagrams were processed by (Image $J$ ) software

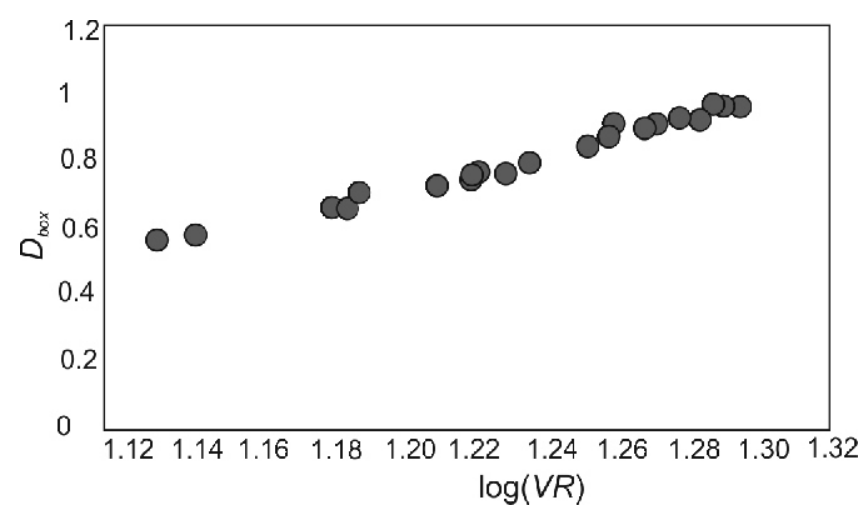

Fig. 14. Variation of $D_{b o x}$ vs. $\log (V R)$ for the MMEs in the DBG 

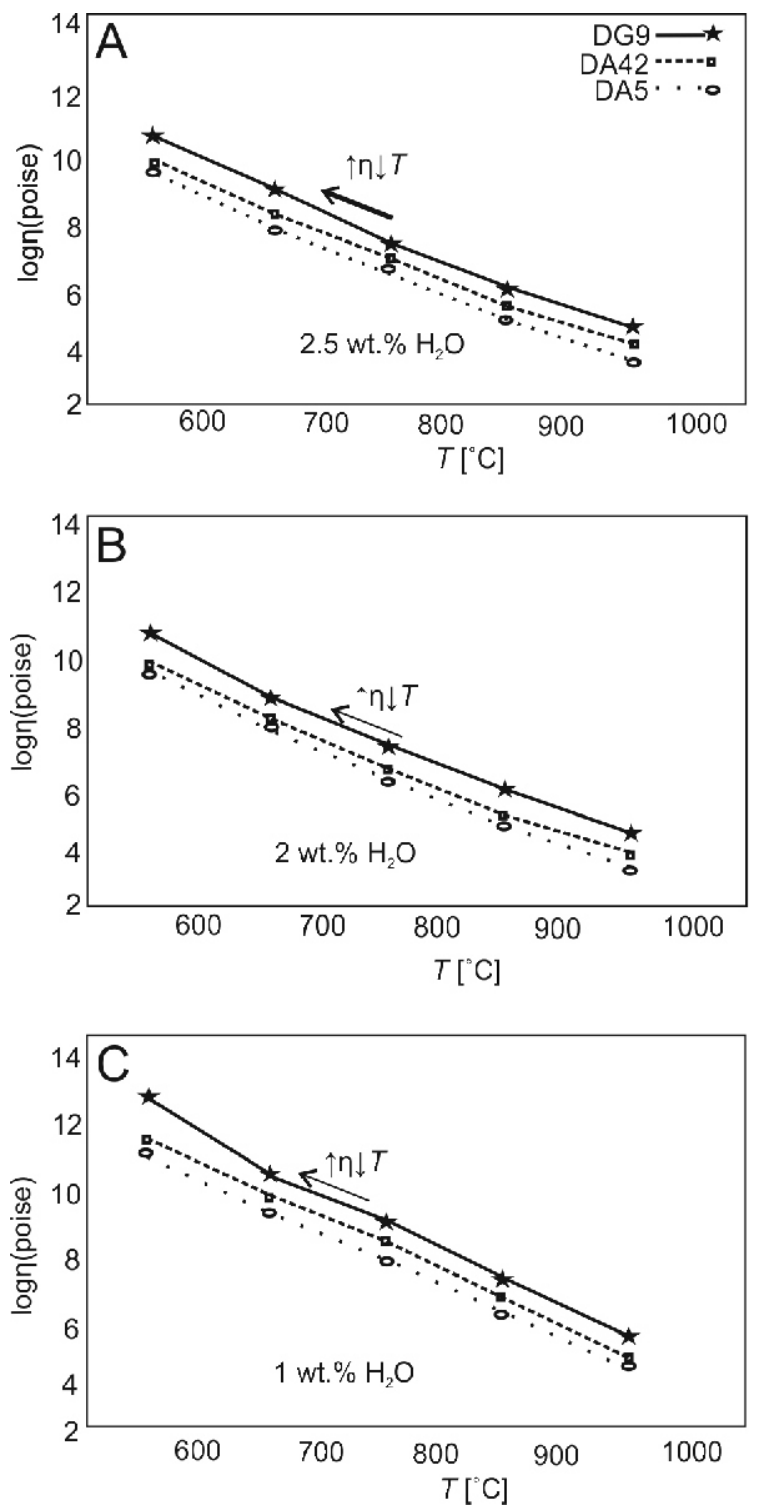

Fig. 15. Diagrams of measured viscosities versus different temperatures for the granodiorite (DG9) and enclave (DA1 and DA42) melts

A - with 2.5 wt. $\% \mathrm{H}_{2} \mathrm{O}$ content; B - with 2 wt. $\% \mathrm{H}_{2} \mathrm{O}$ content, $\mathbf{C}$ - with 1 wt. $\% \mathrm{H}_{2} \mathrm{O}$ content; see text for more discussion

Acknowledgments. We express our gratitude to the editor, W. Granoszewski, for editorial handling and two anonymous reviewers for generous comments and suggestions that helped to improve the standard of the manuscript. Geochemical analyses were carried out at the ALS-Chemex Lab, Loughrea, Ireland. We would like to thank Mr. Mostafaie for technical assistance.

\section{REFERENCES}

Agard, P., Omrani, J., Jolivet, L., Whitechurch, H., Vrielynck, B. Spak-man, W., Monié, P., Meyer, B., Wortel, R., 2011. Zagros orogeny: a subduction-dominated process. Geological Magazine, 148: 692-725.
Alberta, H., Perugini, D., Marti, J., 2014. Fractal analysis of enclaves as a new tool for estimating rheological properties of magmas during mixing: the case of Montan a Reventada (Tenerife, Canary Islands). Pure and Applied Geophysics, doi: 10.1007/s00024-014-0917-5 
Barbarin, B., 1990. Plagioclase xenocrysts and mafic magmatic enclaves in some granitoids of the Sierra Nevada Batholith, California. Journal of Geophysical Research, 95: 17747-17756.

Barbarin, B., 2005. Mafic magmatic enclaves and mafic rocks associated with some granitoids of the central Sierra Nevada batholith, California: nature, origin, and relations with the hosts. Lithos, 80: 155-177.

Baxter, S., Feely, M., 2002. Magma mixing and mingling textures in granitoids: examples from the Galway Granite, Connemara, Ireland. Mineralogy and Petrology, 76: 63-74.

Berberian, M., King, G.C.P., 1981. Towards a palaeogeography and tectonic evolution of Iran. Canadian Journal of Earth Sciences, 18: 210-265.

Best, M., 1982. Igneous and Metamorphic Petrology. Freeman, San Francisco.

Boudreau, A.E., 1999. PELE - a version of the MELTS software program for the PC platform. Computers \& Geosciences, 25: 201-203.

Boynton, W.V., 1984. Geochemistry of the rare earth elements: meteorite studies. In: Rare Earth Element Geochemistry (ed. P. Henderson): 63-114. Elsevier, Amsterdam.

Bussy, F., Ayrton, S., 1990. Quartz textures in dioritic rocks of hybrid origin. Schweizerische Mineralogische und Petrographische Mitteilungen, 70: 223-235.

Castro, A., 2013. The off-crust origin of granite batholiths. Geoscience Frontiers, 5: 63-75.

Chappell, B.W., White, A.J.R., 1974. Two contrasting granite types. Pacific Geology, 8: 173-174.

Chen, B., Chen, Z.C., Jahn, B.M., 2009. Origin of mafic enclaves from the Taihang Mesozoic orogen, north China craton. Lithos, 110: 343-358.

Clemens, J.D., Stevens, G., 2012. What controls chemical variation in granitic magmas? Lithos, 134(135): 317-329

Collins, W.J., 1996. Lachlan Fold Belt granitoids: products of three-component mixing. Transactions of the Royal Society of Edinburgh Earth Sciences, 87: 171-181.

Drummond, M.S., Defant, M.J., 1990. A model for trondhjemite-tonalite-dacite genesis and crustal growth via slab melting: Archean to modern comparisons. Journal of Geophysics Research, 95: 21503-21521.

Eghlimi, B., 2000. Geological map of Danesfahan (Khiaraj) scale 1:100,000 (in Persian). Geological Survay of Iran, Tehran, Iran.

Farner, M.J., Lee, C.T.A., Putirka, K.D., 2014. Mafic-felsic magma mixing limited by reactive processes: a case study of biotite-rich rinds on mafic enclaves. Earth and Planetary Science Letter, 393: $49-50$

Fourcade, S. and Allègre, C.J., 1981. Trace element behavior in granite genesis: a case study of the calc-alkaline plutonic association from the Querigut complex (Pyrenees, France). Contributions to Mineralogy and Petrology, 76: 177-195.

Frost, B.R., Barnes, C.G., Collins, W.J., Arculus, R.J., Ellis, D.J., Frost, C.D., 2001. A geochemical classification for granitic rocks. Journal of Petrology, 42: 20-33.

Giordano, D., Russell, J.K., and Dingwell, D.B., 2008. Viscosity of magmatic liquids: a model. Earth and Planetary Science letters, 271: 123-134.

Green, T.H., 1995. Significance of $\mathrm{Nb} / \mathrm{Ta}$ as an indicator of geochemical processes in the crust mantle system. Chemical Geology, 120: 347-359.

Grove, D.C., and Sando, T.W., 1982. Origin of calc-alkaline series lavas at Medicine Lake Volcano by fractionation, assimilation and mixing. Contributions to Mineralogy and Petrology, $\mathbf{8 0}$ 160-182.

Hildreth, W., Moorbath, S., 1988. Crustal contribution to arc magmatism in the Andes of centeral Chile. Contributions to Mineralogy and Petrology, 98: 455-489.

Hofmann, A.W., White, M., 1983. Ba, Rb and Cs in the earth mantle. Naturforsch, 38: 258-266.

Huang, H., Niu, Y., Zhao, Z., Hei, H., Zhu, D., 2011. On the enigma of $\mathrm{Nb}-\mathrm{Ta}$ and $\mathrm{Zr}-\mathrm{Hf}$ fractionation a critical review. Journal of Earth Science, 22: 52-66.
Hu, J., Jian, Sh.Y., Zhao, H.X., Shao, Y., Zhang, Z.Z., Xiao, E., Wang, Y.F., Dai, B.Z. and Li, H.Y., 2012. Geochemistry and petrogenesis of the Huashan granites and their implications for the Mesozoic tectonic setting in the Xiaoqinling gold mineralization belt, NW China. Journal of Asian Earth sciences, 56:276-289.

Kananian, A., Sarjoughian, F., Nadimi, A.R., Ahmadian, J., Ling. W., 2014. Geochemical characteristics of the Kuh-e Dom intrusion, Urumieh-Dokhtar Magmatic Arc (Iran): implications for source regions and magmatic evolution. Journal of Asian Earth Sciences, 90: 137-148.

Karsli, O., Chen, B., Aydin, F., Şen, C., 2007. Geochemical and $\mathrm{Sr}-\mathrm{Nd}-\mathrm{Pb}$ isotopic compositions of the Eocene Dölek and Sariçiçek Plutons, Eastern Turkey: Implications for magma interaction in the genesis of high-K calc-alkaline granitoids in a post-collision extensional setting. Lithos, 98: 7-96.

Kemp, A.I., Hawkesworth, C.J., Foster, G.L., Paterson, B.A., Woodhead, J.D., Hergt, J.M., Gray, C.M., Whitehouse, M.J., 2007. Magmatic and crustal differentiation history of granitic rocks from Hf-O isotopes in zircon. Science, 315: 980-983.

Kretz, R., 1983. Symbols for rock-forming minerals. American Mineralogist, 68: 277-279.

Kumar, S., 2010. Mafic to hybrid microgranular enclaves in the Ladakh batholith, northwestern Himalaya: implications on calc-alkaline magma chamber processes. Journal of Geological Society of India, 6: 5-25.

Kumar, S., Pieru, T., 2010. Petrography and major element geochemistry of microgranular enclaves and Neoproterozoic granitoids of South Khasi, Meghalaya: evidence of magma mixing and alkali diffusion. Journal of Geological Society India, 76: 345-360.

Kumar, S., Rino, V., Pal, A.B., 2004. Field evidence of magma mixing from microgranular enclaves hosted in Palaeoproterozoic Malanjkhand granitoids, central India. Gondwana Research, 7: 539-548.

Landenberger, B., Collins, W.J., 1996. Derivation of A-type granites from a dehydrated charnockitic lower crust: evidence from the Chaelundi complex, Eastern Australia. Journal of Petrology, 37: 145-170.

Laumonier, M., Scaillet, B., Pichavant, M., Champallier, R., Andujar, J., Arbaret, L., 2014. On the conditions of magma mixing and its bearing on andesite production in the crust. Nature Cominucation, article number: 5607 , doi: $10.1038 /$ ncomms 6607

Lesher, C.E., 1990. Decoupling of chemical and isotopic exchange during magma mixing. Nature, 344: 235-237.

Liu, Z., Jiang, Y.H., Jia, R.Y., Zhao, P., Zhou, Q., 2015. Origin of Late Triassic high-K calc-alkaline granitoids and their potassic microgranular enclaves from the western Tibet Plateau, northwest China: implications for Paleo-Tethys evolution. Gondwana Research, 27: 326-341.

Mandelbrot, B.B., 1982. The Fractal Geometry of Nature. W.H. Freeman, New York.

Mandelbrot, B.B., 1989. Fractal geometry: what is it, and what does it do? In: Fractals in the Natural Sciences (eds. F.R.S Fleischmann, D. Tildesley and R.C. Ball). Princeton University Press, Princeton NJ.

Maniar, P.D., Piccoli, P.M., 1989. Tectonic discrimination of granitoids. Geology Society of American Bulletin, 101: 635-643.

Moradian, A., 1997. Geochemistry, Geochronology and Petrography of Feldspathoid Bearing Rocks in Urumieh-Dokhtar Volcanic Belt, Iran. Unpublished Ph.D thesis, University of Wollongong, Australia.

Morata, D., Oliva, C., Cruz, R.D.I., Suarez, M., 2005. The Bandurrias gabbro: Late Oligocene alkaline magmatism in the Patagonian Cordillera. Journal of South American Earth Sciences, 18: 147-162.

Patiño Douce, A.E., 1999. What do experiments tell us about the relative contributions of crust and mantle to the origin of granitic magmas? Geological Society of London Special Publications, 168: 55-75.

Patiño Douce, A.E., Johnston, A.D., 1991. Phase equilibria and melt productivity in the pelitic system: implications for the origin 
of peraluminous granitoids and aluminous granulites. Contributions to Mineralogy and Petrology, 107: 202-218.

Perugini, D., Poli, G., 2000. Chaotic dynamics and fractals in magmatic interaction processes: a different approach to the interpretation of mafic microgranular enclaves. Earth and Planetary Science Letters, 175: 93-103.

Perugini, D., Poli, G., 2005. Viscous fingering during replenishment of felsic magma chambers by continuous inputs of mafic magmas: field evidence and fluid-mechanics experiments. Geology, 33: 5-8.

Perugini, D., Poli, G., 2012. The mixing of magmas in plutonic and volcanic environments: analogies and differences. Lithos, 153: 263-279.

Perugini, D., Poli, G., Christofides, G., Eleftheriadis, G., 2003 Magma mixing in the Sithonia plutonic complex, Greece: evidence from mafic microgranular enclaves. Mineralogy and $\mathrm{Pe}-$ trology, 78: 173-200.

Perugini, D., De Campos, C.P., Dingwell, D.B., Petrelli,M., Poli, G., 2008. Trace element mobility during magma mixing: preliminary experimental results. Chemical Geology, 256: 146-157.

Rapp, R.P., Watson, E.B., 1995. Dehydration melting of metabasalt at 8-32 kbar: implications for continental growth and crust-mantle recycling. Journal of Petrology, 36: 891-931.

Rudnick, R.L., Fountain, D.M., 1995. Nature and composition of the continental crust: a lower crustal perspective. Reviews of Geophysics, 33: 267-309.

Safarzadeh, E., 2007. Petrogheraphy and petrology of Haji Abad pluton (in Persian with English abstract). MSc. thesis, University of Shahid Beheshti, Tehran, Iran.

Sawka, W.N., 1988. REE and trace element variations in accessory minerals and hornblende from the strongly zoned McMurry Meadows pluton, California. Transactions of the Royal Society of Edinburgh, 79: 157-168.

Sisson, T.W., Ratajeski, K., Hankins, W.B., Glazner, A.F., 2005. Voluminous graniticmagmas from common basaltic sources. Contributions to Mineralogy and Petrology, 148: 635-661.

Słaby, E., Smigielski, M., Smigielski, T., Domonik, A., Simon, K., Kronz, A., 2011. Chaotic three-dimensional distribution of $\mathrm{Ba}$, $\mathrm{Rb}$, and $\mathrm{Sr}$ in feldspar megacrysts grown in an open magmatic system. Contribution to Mineralogy and Petrology, 162: 909-927.

Shellnutt, J.G., Wang, C.Y., Zhou, M.F., Yang, Y., 2009. Zircon $\mathrm{Lu}-\mathrm{Hf}$ isotopic compositions of metaluminous and peralkaline A-type granitic plutons of the Emeishan large igneous province
(SW China): constraints on the mantle source. Journal of Asian Earth Science, 35: 45-55.

Sun, S.S., McDonough, W.F., 1989. Chemical and isotopic systematics of oceanic basalts: implications for mantle composition and processes. Geological Society London, Special Publications, 42: 313-345.

Tabakhe Shabani, A.A., 1990. Petrogheraphy and petrology of igneous plutons of south Boien Zahra. (in Persian with English abstract). MSc. thesis, University of Kharazmi, Karaj, Iran.

Tindle, A.G., 1991. Trace element behaviour in microgranular enclaves from granitic rocks. In: Enclaves and Granite Petrology, Developments in Petrology (eds. J. Didier and B. Barbarin): 13: 13-33. Elsevier, Amsterdam.

Vernon, R.H., 1983. Restites, xenoliths and microgranitoid enclaves in granites. Journal and proceedings of the Royal Society of New South Wales (London), 116: 77-103.

Vernon, R.H., Etheridge, M.A., Wall, V.J., 1988. Shape and microstructures of microgranitoid enclaves: indicators of magma mingling and flow. Lithos, 22: 1-11.

Vogel, T.A., Younker, L.W., Wilband, J.T., Kampueller, E., 1984. Magma mixing: the Marsco suite, Isle of Skye, Scotland. Contributions to Mineralogy and Petrology, 87: 231-241.

Wang, Q., McDermott, F., Xu, J.F., Bellon, H., Zhu, Y.T., 2005. Cenozoic K-rich adakitic volcanic rocks in the Hohxil area, northern Tibet: lower-crustal melting in an intracontinental setting. Geology, 33: 465-468.

Watson, E.B., 1981. Diffusion in magmas at depth in the earth: the effects of pressure and dissolved $\mathrm{He}_{2} \mathrm{O}$. Earth Planetary Science Letter, 52: 291-301.

Wilson, M., 1989. Igneous petrogenesis: Interpretation and Application. Chapman and Hall, London.

Wilson, M., 2007. Igneous Petrogenesis, A Global Tectonic Approach. Springer.

White, A.J.R., Chappell, B.W., Wyborn, D., 1999. Application of the restite model to the Deddick Granodiorite and its enclaves a reinterpretation of the observations and data of Maas, R. Nicholls, I.A., and Legg, C., 1997. Jornal of Petrology, 40: 413-421.

Zhao, K.D., Jiang, S.Y., Yang, S.Y., Dai, B.Z., Lu, J.J., 2012. Mineral chemistry, trace elements and SrlNdlHf isotope geochemistry and petrogenesis of Cailing and Furong granites and mafic enclaves from the Qitianling batholith in the Shi-Hang zone, South China. Gondwana Research, 22: 310-324. 